\title{
Mineral Resources of the Notch Peak Wilderness Study Area, Millard County, Utah
}
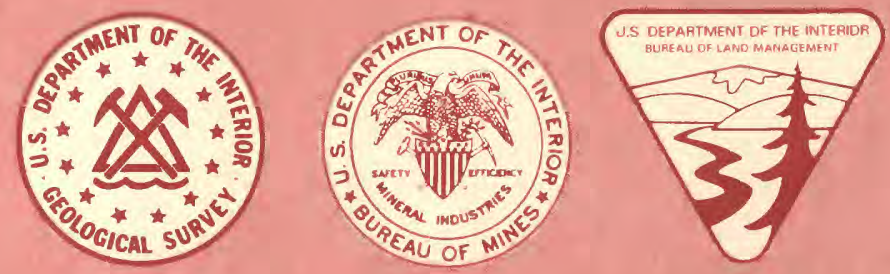

\section{U.S. GEOLOGICAL SURVEY BULLETIN 1749-C}
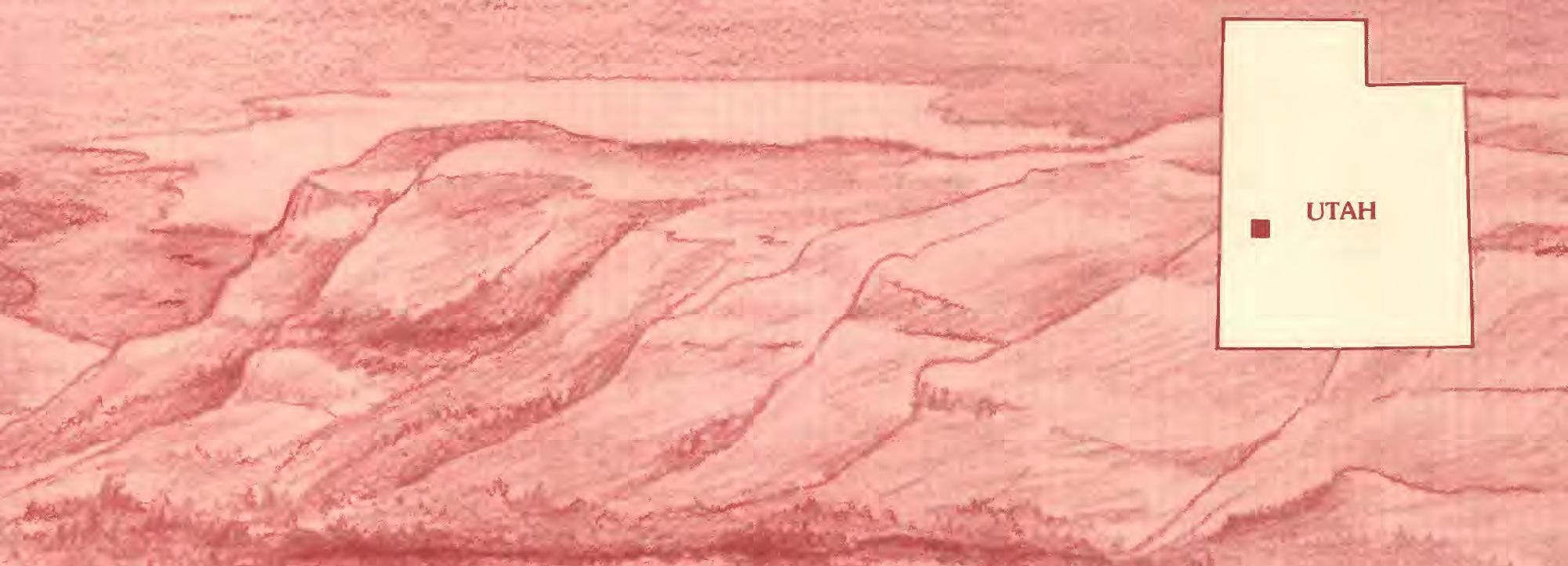

Chapter C

Mineral Resources of the

Notch Peak Wilderness Study Area, Millard County, Utah

By DOUGLAS B. STOESER, DAVID L. CAMPBELL, VICTOR LABSON, DAVID R. ZIMBELMAN, MELVIN H. PODWYSOCKI, DAVID W. BRICKEY, JOSEPH S. DUVAL, and KENNETH L. COOK U.S. Geological Survey

WILLIAM LUNDBY

U.S. Bureau of Mines

U.S. GEOLOGICAL SURVEY BULLETIN 1749

MINERAL RESOURCES OF WILDERNESS STUDY AREAS-WEST-CENTRAL UTAH 


\title{
DEPARTMENT OF THE INTERIOR
}

MANUEL LUJAN, JR., Secretary

\author{
U.S. GEOLOGICAL SURVEY
}

Dallas L. Peck, Director

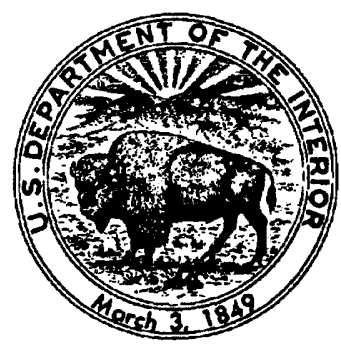

Any use of trade, product, or firm names in this publication is for descriptive purposes only and does not imply endorsement by the U.S. Government.

UNITED STATES GOVERNMENT PRINTING OFFICE: 1990

For sale by the

Books and Open-File Reports Section

U.S. Geological Survey

Federal Center

Box 25425

Denver, CO 80225

\section{Library of Congress Cataloging-in-Publication Data}

Mineral resources of the Notch Peak Wilderness Study Area, Millard County,

Utah / by Douglas B. Stoeser ... [et al.].

p. cm.-(U.S. Geological Survey bulletin ; 1749-C)

(Mineral resources of wilderness study areas - west-central Utah)

Includes bibliographical references.

Supt. of Docs. no.: I 19.3:1749-C

1. Mines and mineral resources-Utah-Notch Peak Wilderness.

2. Notch Peak Wilderness (Utah) I. Stoeser, D.B. II. Series. III. Series:

Mineral resources of wilderness study areas - west-central Utah.

QE75.B9

no. $1749-\mathrm{C}$

[TN24.U8 ]

$557.3 \mathrm{~s}-\mathrm{dc} 20$

[553'.09792'45] 


\section{STUDIES RELATED TO WILDERNESS}

\section{Bureau of Land Management Wilderness Study Areas}

The Federal Land Policy and Management Act (Public Law 94-579, October 21, 1976) requires the U.S. Geological Survey and the U.S. Bureau of Mines to conduct mineral surveys on certain areas to determine the mineral values, if any, that may be present. Results must be made available to the public and be submitted to the President and the Congress. This report presents the results of a mineral survey of a part of the Notch Peak (UT-050-078) Wilderness Study Area, Millard County, Utah. 


\section{CONTENTS}

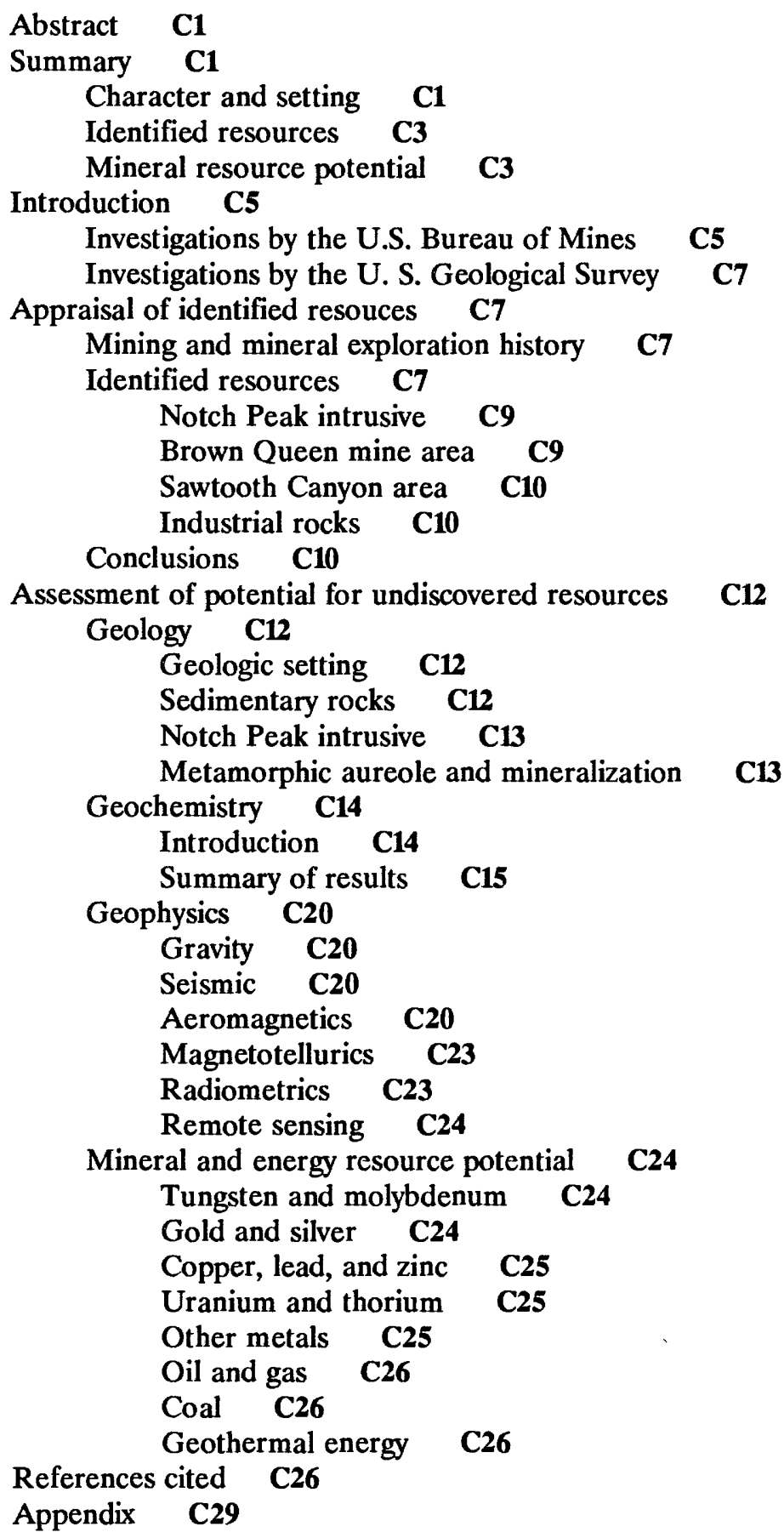


PLATE

[Plate is in pocket]

1. Map showing mineral resource potential and geology of the Notch Peak Wilderness Study Area, Millard County, Utah.

\section{FIGURES}

1-4. Maps showing:

1. Location of the Notch Peak Wilderness Study Area C2

2. Mineral resource potential of the Notch Peak Wilderness Study Area C4

3. Location of the Notch Peak mining district, mines, and prospects in and near the Notch Peak Wilderness Study Area C6

4. Oil and gas leases and lease applications in and near the Notch Peak Wilderness Study Area C8

5. Simplified geologic map of the Notch Peak Wilderness Study Area and vicinity C11

6. Map showing location of stream-sediment sample sites, drainage basins, and anomalous elements in heavy-mineral-concentrate samples in and near the Notch Peak Wilderness Study Area C18

7. Map showing location of sample sites and anomalous elements for rock samples in and near the Notch Peak Wilderness Study Area C19

8. Complete Bouguer gravity anomaly map of the Notch Peak Wilderness Study Area and vicinity

C21

9. Aeromagnetic map of the Notch Peak Wilderness Study Area and vicinity C22

\section{TABLES}

1. Summary of geochemical anomalies for selected elements in heavy-mineral concentrates of stream-sediment samples, Notch Peak Wilderness Study Area, Utah C15

2. Summary of geochemical anomalies for selected elements in rock samples, Notch Peak Wilderness Study Area, Utah 


\title{
Mineral Resources of the Notch Peak Wilderness Study Area, Millard County, Utah
}

\author{
By Douglas B. Stoeser, David L. Campbell, Victor Labson, \\ David R. Zimbelman, Melvin H. Podwysocki, \\ David W. Brickey, Joseph S. Duval, and Kenneth L. Cook' \\ U.S. Geological Survey \\ William Lundby \\ U.S. Bureau of Mines
}

\section{ABSTRACT}

The Notch Peak Wilderness Study Area (UT-050-078) is located in the central House Range, Millard County, west-central Utah, about $\mathbf{4 3}$ miles west of the city of Delta. The geology of the study area consists of a Jurassic granite that intrudes gently dipping Cambrian and Ordovician limestone and shale. The northern part of the study area includes part of the Notch Peak mining district, which has produced tungsten from mines within and near the study area. Mining within the district, but outside the study area, included gold placer mining. Mineralization in the district is primarily related to the Notch Peak intrusive. A resource of 775 short tons, which averages 0.47 percent tungsten trioxide was defined at the Brown Queen mine in the northern part of the study area. Limestone and sand and gravel occur within the study area. For the purposes of assessing mineral resource potential the study area was divided into five subareas: the granite (Notch Peak intrusive), the metamorphic contact zone of the granite, the area north of the contact zone, the area south of the contact zone, and a small drainage in the southwestern part of the study area. The Notch Peak intrusive has moderate mineral resource potential for undiscovered molybdenum, gold, copper, uranium, and thorium, and low mineral resource potential for undiscovered tungsten, silver, lead, and zinc. The metamorphic contact zone of the granite has high mineral resource potential for undiscovered tungsten, and moderate

Manuscript approved for publication, October 16, 1989.

1 University of Utah. mineral resource potential for undiscovered molybdenum, gold, silver, copper, lead, zinc, uranium, and thorium. The area to the north of the contact zone of the granite has moderate mineral resource potential for undiscovered tungsten, molybdenum, gold, silver, copper, lead, and zinc, and low mineral resource potential for undiscovered uranium and thorium. The area to the south of the contact zone of the granite has low mineral resource potential for undiscovered tungsten, molybdenum, gold, silver, copper, lead, zinc, uranium, and thorium. The area underlying a small drainage in the southwestern part of the study area has moderate mineral resource potential for undiscovered tungsten and molybdenum, and low mineral resource potential for undiscovered gold, silver, copper, lead, zinc, uranium, and thorium. The entire study area has moderate resource potential for undiscovered oil and gas. The entire study area has low resource potential for all other metals, coal, and geothermal energy.

\section{SUMMARY}

\section{Character and Setting}

At the request of the Bureau of Land Management, 28,000 acres of the Notch Peak Wilderness Study Area were studied. In this report the studied area is called the "wilderness study area" or simply the "study area." The study area lies in the central part of the House Range, which is a classic range of the Basin and Range physiographic province in Utah (fig. 1). The central 


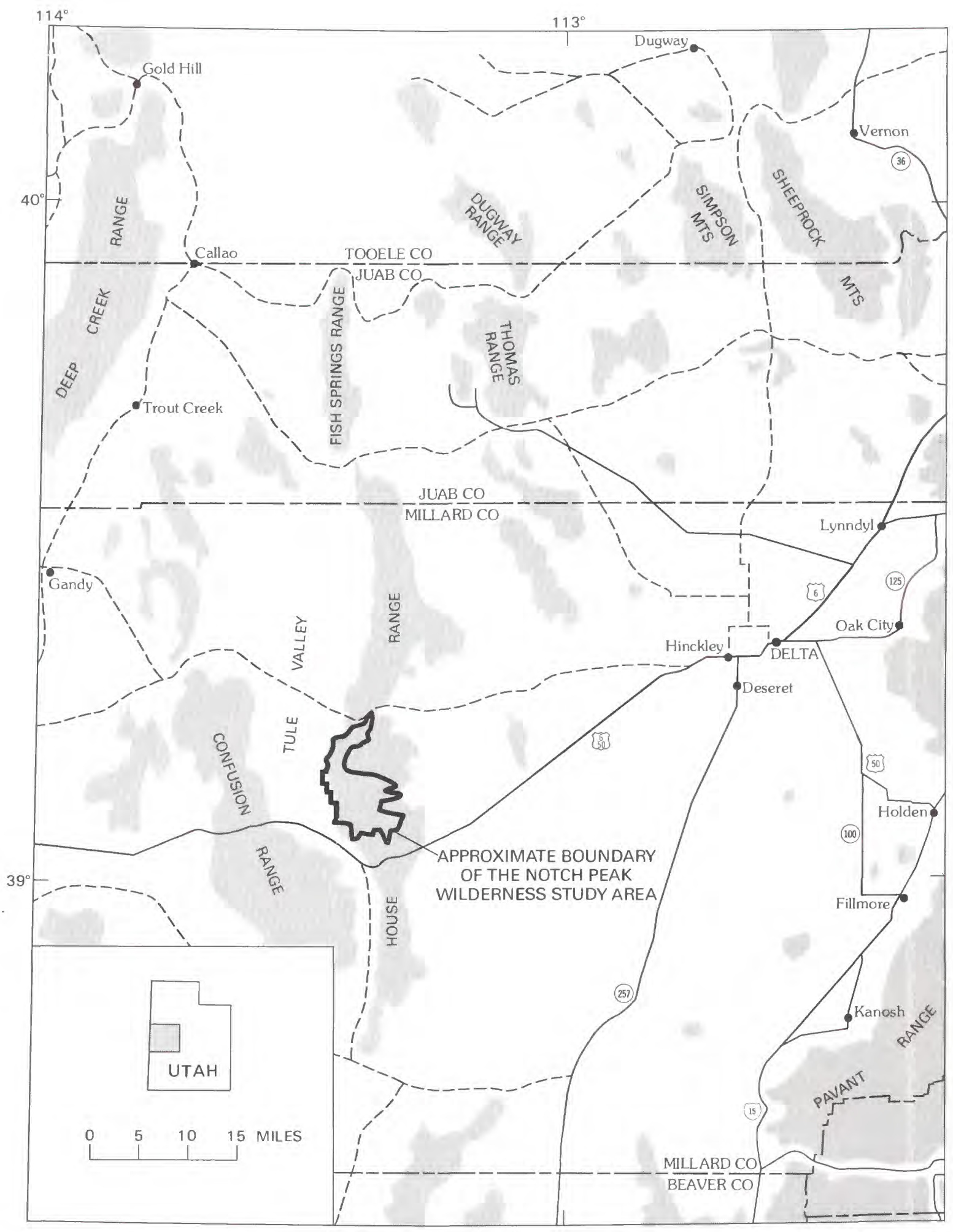

Figure 1. Location of the Notch Peak Wilderness Study Area.

House Range has a steep, rugged west face but slopes gently to the east. Maximum relief from the floor of Tule Valley on the west to Notch Peak (9,655 ft), the highest peak in the central part of the range, is slightly more than
$5,000 \mathrm{ft}$ (fig. 1, pl. 1). Bedrock is well exposed. Although the region is part of the Sevier Desert, much of the area above $7,000 \mathrm{ft}$ is wooded with juniper, piñon pine, and local aspen. 
The House Range is an eastward-tilted upthrown block with a range-front fault on the west side. The geology of the study area is simple and consists of a Jurassic granite (the Notch Peak intrusive) that intrudes gently south dipping Cambrian and Ordovican limestones and shales. Deep seismic reflection data show that the central House Range is underlain by several detachment surfaces (shallow-dipping major faults), which were formed by regional, easterly directed thrusting during the late Mesozoic.

\section{Identified Resources}

Tungsten, gold, molybdenum, copper, and uranium mineralization is associated with the Notch Peak intrusive. Tungsten skarns adjacent to and placer gold in and adjacent to the granite have been mined in the past and currently are being mined. The area of mines and prospects constitutes the Notch Peak mining district. The western and northern parts of this district lie within the study area.

Tungsten and base and precious metals have been concentrated in skarn and idocrase marble zones at the margins of the Notch Peak intrusive. Recorded production of tungsten trioxide $\left(\mathrm{WO}_{3}\right)$ from these zones has exceeded 1,000 short tons (st). Gold production from placers to the east of the study area (Amasa Valley) has not been documented, but 2- to 3-man placer operations currently are being conducted. A resource of 775 st that averages 0.47 percent $\mathrm{WO}_{3}$ was defined at the Brown Queen mine within the study area. There are also tungsten and gold occurrences near the granite contact.

Sand and gravel occur within the study area, but prevalence of these materials throughout the region precludes the development of these resources in the study area in the foreseeable future.

\section{Mineral Resource Potential}

Almost all known mineralization within the study area is associated with the granite at Notch Peak (fig. 2). The most important mineralization is tungsten skarn replacement bodies after limestone, which occur within the contact metamorphic aureole of the granite and are distributed along the entire margin of the granite. These skarns consist of garnet, pyroxene, and as much as a few percent scheelite $\left(\mathrm{CaWO}_{4}\right)$. Some of these skarns have been mined for tungsten, and the mineral resource potential for undiscovered tungsten within the contact zone of the granite is high. In addition, based on tungsten geochemical anomalies, the part of the study area north of the contact zone and the area underlying a drainage in the southwest part of the study area have moderate mineral resource potential for undiscovered tungsten, and the rest of the study area has low mineral resource potential for undiscovered tungsten.

Within the study area, minor molybdenum, copper, uranium, and thorium occurrences are associated with the granite along its western margin. Based on these occurrences as well as geochemical anomalies, the mineral resource potential for undiscovered molybdenum, copper, lead, zinc, uranium, and thorium is moderate within the contact zone. In the area north of the contact zone, the mineral resource potential is moderate for undiscovered molybdenum, copper, lead, and zinc, and is low for undiscovered uranium and thorium. Within the granite there is moderate mineral resource potential for undiscovered molybdenum, copper, uranium, and thorium, and low mineral resource potential for undiscovered lead and zinc. To the south of the contact zone, the mineral resource potential for undiscovered tungsten, molybdenum, copper, uranium, thorium, lead, and zinc is low except for the area underlying a small drainage, which has moderate mineral resource potential for both undiscovered tungsten and molybdenum.

Two different deposit types of gold mineralization were considered for the study area. The first type is lode gold associated with the granite at Notch Peak. Gold associated with the granite occurs in an area of veining and alteration in the eastern part of the granite outside of the study area and in the tungsten skarns that are distributed along the entire margin of the granite. The second type is sediment-hosted disseminated gold mineralization which occurs throughout much of the Basin and Range province. Based on these models, the study area has moderate mineral resource potential for undiscovered gold within the granite, its contact zone, and the area north of the contact zone, and has low mineral resource potential in the area south of the granite. In addition, the contact zone and the area north of the zone have moderate mineral resource potential for undiscovered silver, and the rest of the study area has low mineral resource potential for undiscovered silver.

The resource potential for all other metals in the wilderness study area is low. The field investigation and geochemical survey did not indicate any evidence for the occurrence of metal deposits other than those discussed above.

The study area is assigned moderate resource potential for undiscovered oil and gas based on three considerations: (1) known source rocks in Cambrian and Lower Ordovician sedimentary rocks, (2) possible Paleozoic and (or) Mesozoic rocks beneath arched detachment-fault surfaces, and (3) an optimum degree of thermal maturation for oil and gas generation.

Because of the ages and types of the sedimentary rocks in the study area, there is low resource potential for 


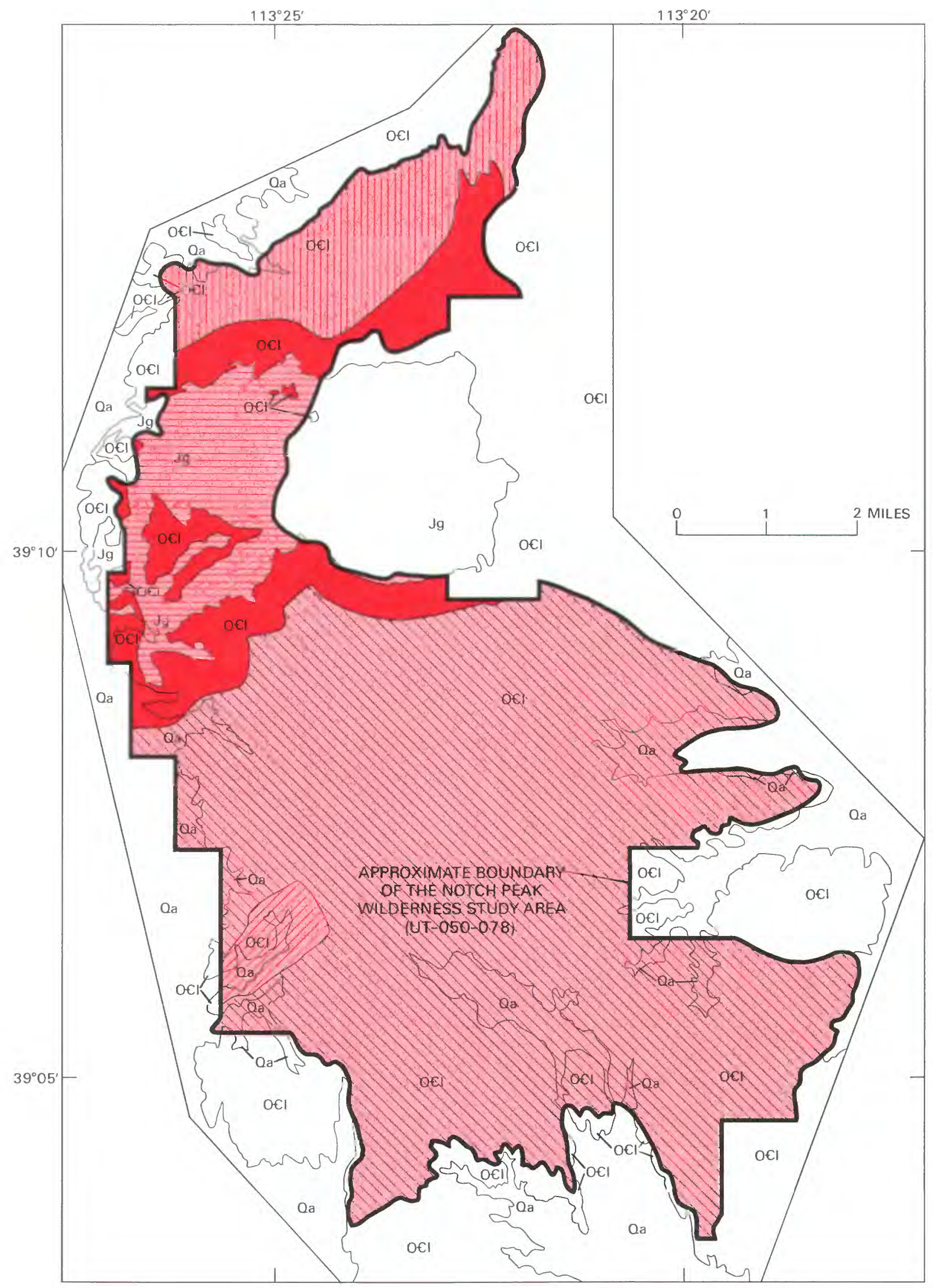

Figure 2 (above and facing page). Mineral resource potential of the Notch Peak Wilderness Study Area. 


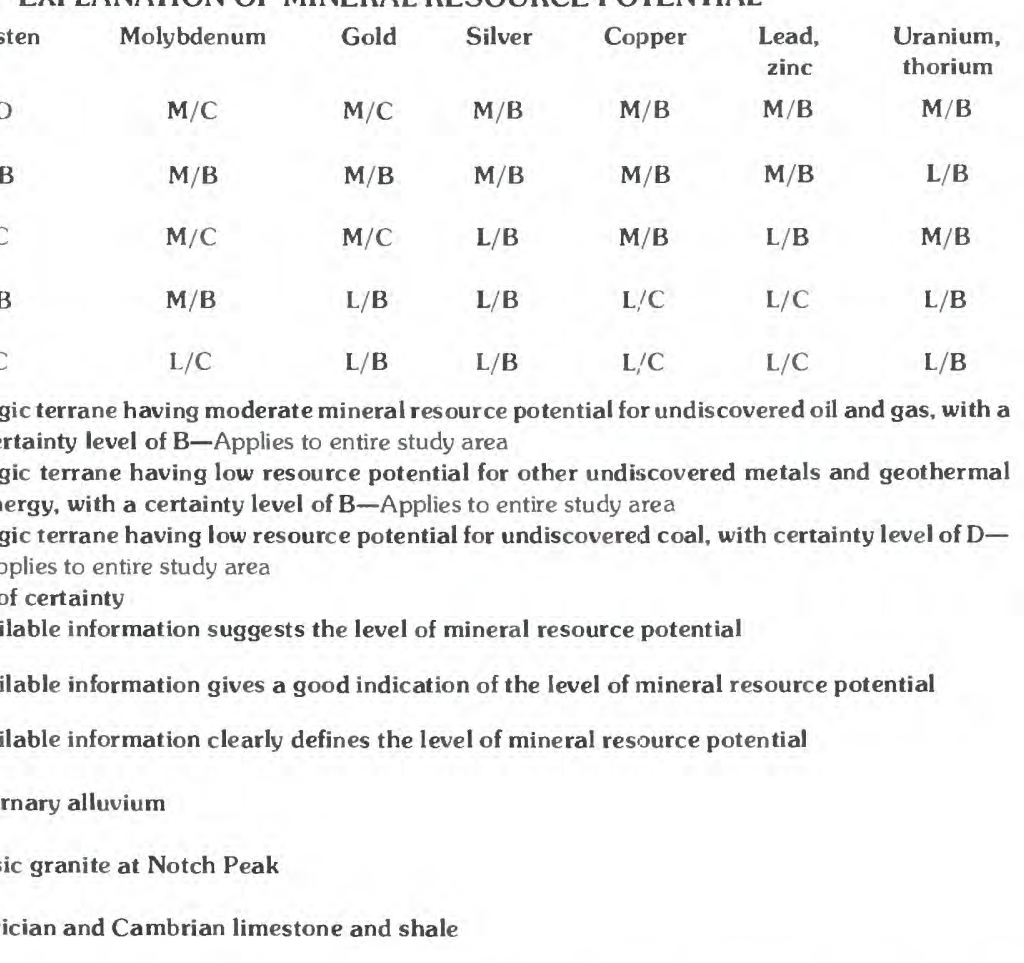

undiscovered coal. Because of the lack of thermal springs, the resource potential for undiscovered geothermal energy is low.

\section{INTRODUCTION}

This report presents an evaluation of the mineral endowment (identified resources and mineral resource potential) of the Notch Peak Wilderness Study Area (UT-050-078) and is the product of several separate studies by the U.S. Bureau of Mines (USBM) and the U.S. Geological Survey (USGS). Identified resources are classified according to the system of the U.S. Bureau of Mines and U.S. Geological Survey (1980), which is shown in the Appendix of this report. Identified resources are studied by the USBM. Mineral resource potential is the likelihood of occurrence of undiscovered metals and nonmetals, industrial rocks and minerals, and of undiscovered energy sources (coal, oil, gas, oil shale, and geothermal sources). It is classified according to the system of Goudarzi (1984) and is shown in the Appendix. Undiscovered resources are studied by the USGS.

At the request of the U.S. Bureau of Land Management (BLM), 28,000 acres of the Notch Peak Wilderness Study Area in Millard County, Utah, were studied. The study area is located in the central part of the House Range in western Utah, $43 \mathrm{mi}$ west-southwest of Delta, which is the nearest town, and 135 mi southwest of Salt Lake City. Access is provided by combined U.S. Highways 6 and 50 just south of the study area and by improved dirt roads on all sides (figs. 1,2). The central House Range contains three major canyons on its eastern flank: Sawtooth, Miller, and North Canyons (pl. 1). All of these canyons allow access by dirt road to the interior part of the range. An improved dirt road along North Canyon allows easy access to the northeastern boundary of the study area, which is drawn along the ridge axis of the range at an elevation of more than 9,000 $\mathrm{ft}$. The central House Range is asymmetrical; it has a steep, rugged west face but slopes more gently to the east. Maximum relief from the floor of Tule Valley on the west to Notch Peak $(9,655 \mathrm{ft})$, the highest peak in the central part of the range, is slightly more than $5,000 \mathrm{ft}$. Bedrock is well exposed and consists mainly of limestone but also includes granite in the north-central part of the study area. Although the region is part of the Sevier Desert, much of the area above $7,000 \mathrm{ft}$ is wooded with juniper, piñon pine, and local aspen.

\section{Investigations by the \\ U.S. Bureau of Mines}

The USBM studied the mineral resources of the Notch Peak Wilderness Study Area from July to September 1986 (Lundby, 1987). A detailed literature search for pertinent geologic and mining information for the study area and surrounding area was made by USBM personnel prior to the field investigation. BLM and county records were examined for locations of patented 


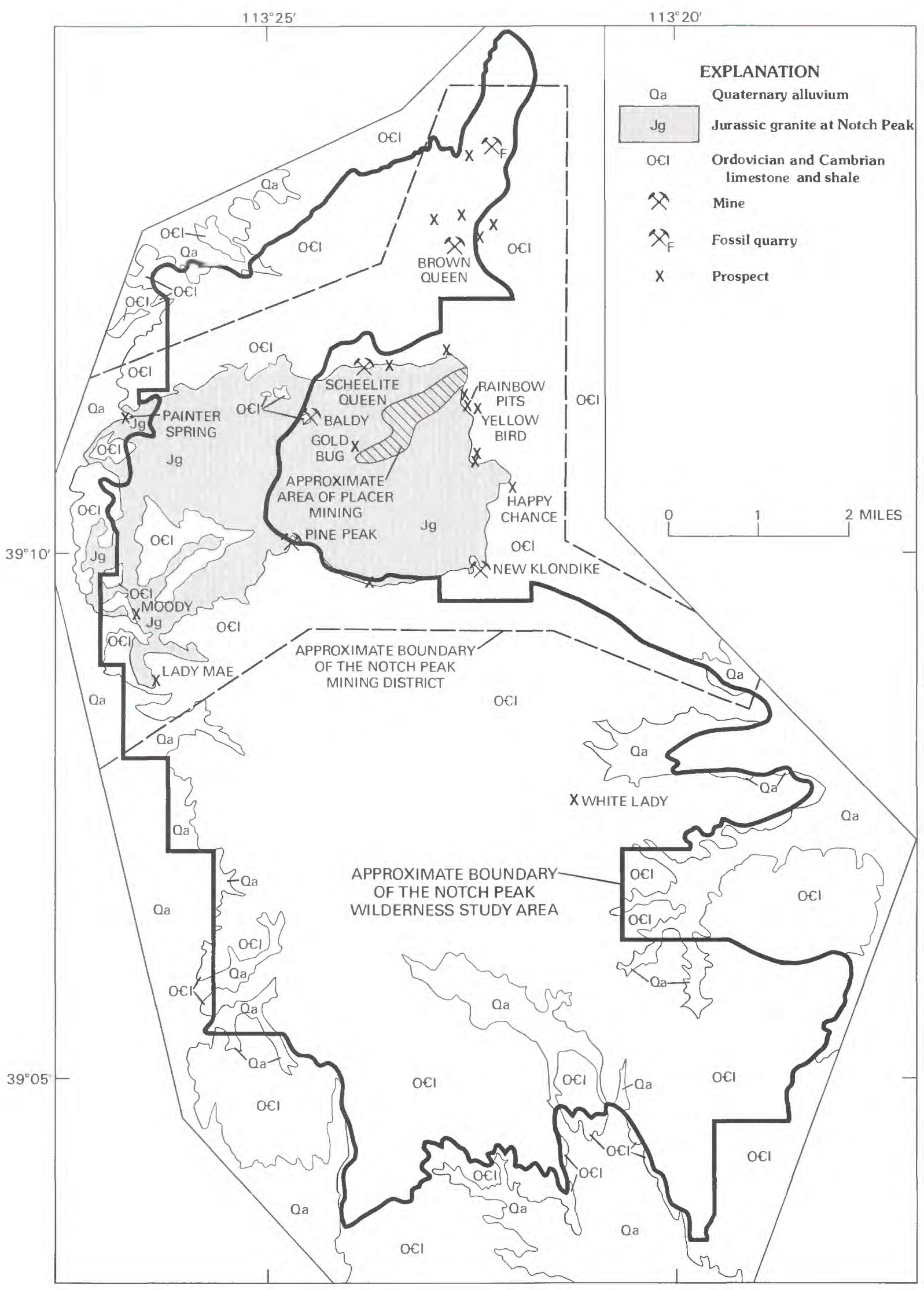


and unpatented mining claims, mineral leases, and oil and gas leases in and near the study area (figs. 3, 4).

The USBM field study concentrated on the examination of known mines, prospects, and mineralized areas inside or within $1 \mathrm{mi}$ of the study area boundary; the peripheral mineral occurrences were examined to determine whether they might extend into, or are similar to those within, the study area. A total of 56 employeedays were spent in the area doing field work. Accessible mine and prospect workings were mapped and sampled. Chip samples were collected across veins, structures, and potentially mineralized outcrops; stream-sediment samples were collected from drainages to aid in the evaluation of exposed mineral occurrences and their extensions and to help identify additional occurrences within the drainages.

A total of 148 samples were collected during the field examination. All samples were analyzed colorimetrically for tungsten; 34 samples were analyzed for copper, lead, zinc, and molybdenum by atomic absorption spectrophotometry (AA); and 114 samples were fire-assayed for gold and silver. Seven samples were analyzed by semiquantitative optical-emission spectrography for 40 elements. Analyses were performed by the USBM Research Center at Reno, Nev., and by Barringer Resources, Inc., Golden, Colo.

\section{Investigations by the U.S. Geological Survey}

Geological, geochemical, and geophysical studies were conducted by the USGS during 1986 and 1987 . The geological map (pl. 1) was modified from Hintze (1974). A geochemical survey of the study area was conducted by D.R. Zimbelman. Aeromagnetic and radiometric data were collected in 1978 as part of the National Uranium Resource Evaluation (NURE) program of the U.S. Department of Energy. Magnetotelluric soundings were made in and near the study area in 1987 by Victor Labson. Gravity data were compiled in 1986-1987 by Kenneth L. Cook ${ }^{2}$ and Viki Bankey. These geophysical data, together with seismic and geoelectrical work done near the study area, were evaluated by D.L. Campbell. Radiometric data were processed and evaluated by J.S. Duval. Remote sensing data were collected by Thematic Mapper satellite and were processed and evaluated by M.H. Podwysocki and D.W. Brickey.

IUniversity of Utah.

Figure 3 (facing page). Location of the Notch Peak mining district, mines, and prospects in and near the Notch Peak Wilderness Study Area. The boundary of the Notch Peak mining district is not formally defined and is here drawn around the main area of mines and prospects.

APPRAISAL OF IDENTIFIED RESOUCES

\section{By William Lundby U.S. Bureau of Mines}

\section{Mining and Mineral Exploration History}

Mineral production from the Notch Peak Wilderness Study Area has been from two areas. Tungsten has been produced from skarns at the margins of the Notch Peak intrusive (Gray, 1956, p. 8, 10), and gold has been mined from placers in Amasa Valley (Gray, 1956, p. 15) These areas collectively constitute the Notch Peak mining district. Figure 3 shows the approximate location of the district, mines, and major prospects of the study area as of 1987.

Recorded production of tungsten (USBM Minerals Yearbooks) shows that about 1,000 st of $\mathrm{WO}_{3}$ were produced from the New Klondike mine from 1942 through 1956; also listed was minor production from the Scheelite Queen in 1943, the Queen of the Hills mine in 1953 (57 st of $\mathrm{WO}_{3}$ ), the Treasure Mountain Mining Company property in $1955\left(\$ 75,000\right.$ worth of $\left.\mathrm{WO}_{3}\right)$, and various unnamed mines in Millard County in 1952, 1955, 1956, and 1977. Gray (1956, p. 8) stated that about 7,000 st of $\mathrm{WO}_{3}$ was mined and stockpiled at the Baldy Peak mine (Pine Peak) and the Rainbow mine during 1954 and 1955. All the production listed was from mines adjacent to the study area and peripheral to the granite intrusion.

Gold and scheelite are known to occur in the gravels in Amasa Valley (pl. 1), and 2- to 3-man placer operations are currently being conducted in the valley.

\section{Identified Resources}

The USBM surveys and studies mines, prospects, and mineralized areas to appraise identified mineral resources. Identified resources, as defined by the U.S. Bureau of Mines and U.S. Geological Survey (1980), are those whose location, grade, quality, and quantity are known or can be estimated from specific geologic evidence. They include economic, marginally economic, and subeconomic components.

Concentrations of tungsten are localized in skarns near the margins of the granite at Notch Peak, which is a Jurassic intrusion. Skarn is a rock composed of calciumand (or) magnesium-bearing silicate minerals derived from nearly pure limestone and (or) dolomite by the introduction of large amounis of silicon, aluminum, iron, and magnesium. Gold and minor base metals also occur within, or peripheral to, the granite (Gehman, 


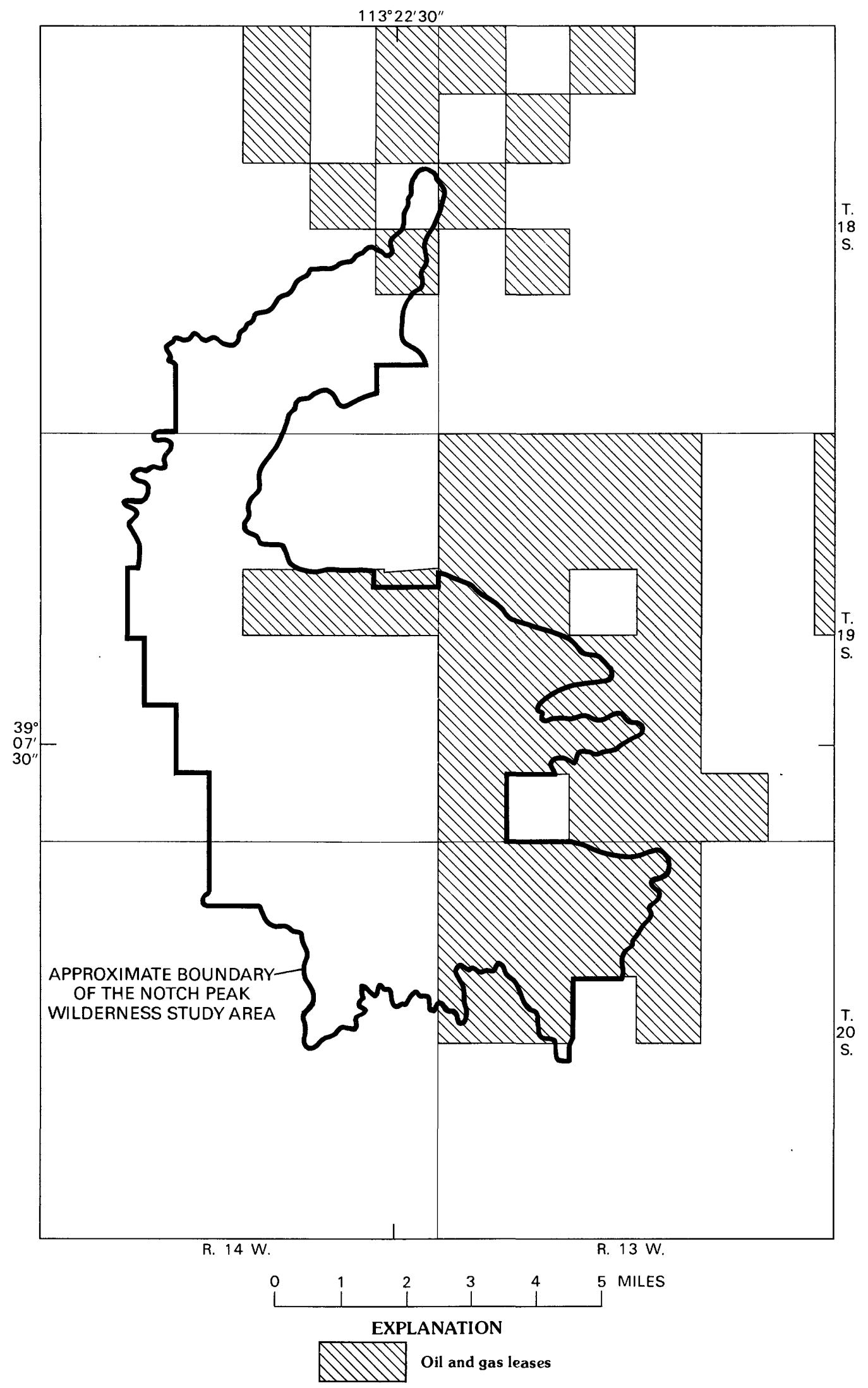

Figure 4. Oil and gas leases in and near the Notch Peak Wilderness Study Area. Oil and gas lease information from the U.S. Bureau of Land Management; current as of July 1986. 
1958; Petersen, 1976; Lundby, 1987). Smith and Smith $(1969$, p. 40$)$ suggested that gold and scheelite were deposited from the same hydrothermal solutions, but that the scheelite deposition extends further away from the granite contact into the limestone wallrock.

\section{Notch Peak Intrusive}

The chief source of metallization in the study area appears to have been the fluids that emanated from the Notch Peak intrusive. Most of the tungsten mineralization has been found in skarns in the contact zone of the granite. The source of gold for the Amasa Valley placers reportedly is a breccia zone in the granite in the central part of the valley (Smith and Smith, 1969, p. 12). Molybdenum has been reported by Gehman (1958, p. 43) from the west margin of the granite, south of Painter Springs.

Thirteen rock samples were collected from granite at the north and south margins of the intrusion within the study area, and 48 rock samples were collected from six adits and four opencuts or prospect pits within $1 / 2 \mathrm{mi}$ of the study area boundary (Lundby, 1987, pl. 1).

Samples from the northern margin of the granite show only a small amount of tungsten; assays range from undetected to 28 parts per million (ppm). The abundance of tungsten along the southern margin was slightly greater and ranged from undetected to $280 \mathrm{ppm}$. Samples collected from the workings at or within $1 / 2 \mathrm{mi}$ of the study area boundary, show similar amounts of tungsten; only three samples exceed $1,000 \mathrm{ppm}$ $\left(0.10\right.$ percent $\mathrm{W}, 0.13$ percent $\left.\mathrm{WO}_{3}\right)$, the greatest being $2,400 \mathrm{ppm}\left(0.24\right.$ percent $\mathrm{W}, 0.30$ percent $\mathrm{WO}_{3}$ ) (Lundby, 1987).

Two prospects, the Moody and Lady Mae, that were not sampled lie within the study area at the southwestern margin of the Notch Peak intrusive (fig. 3). The Moody prospect consists of a south-trending, 40 -ft-long adit in skarn along the granite contact. The skarn contains mainly garnet and pyroxene, as well as minor amounts of molybdenite $\left(\mathrm{MoS}_{2}\right)$, pyrite $\left(\mathrm{FeS}_{2}\right)$, and chalcopyrite $\left(\mathrm{CuFeS}_{2}\right)$. Petersen (1976) reported tungsten contents of 0.15 and 0.26 percent for two samples of the skarn. The Lady Mae prospect consists of a 65 -ft-long adit at the south end of a large granite sill (Petersen, 1976). The sill and host limestone are cut by a vertical aplite dike that contains scheelite, molybdenite, chalcopyrite, and pyrite, as well as scheelite-bearing skarn along its margin (Petersen, 1976). There is no record of production from either prospect, and no tungsten resources were delineated within the study area.

No identified tungsten resources are present along the periphery of the granite within, or extending into, the sampled part of the study area. However, a validity examination by the BLM determined that at the New Klondike mine, in secs. 12 and 13, T. 19 S., R. 14 W., Salt Lake Meridian, Millard County, Utah, a group of nine patented claims contains six orebodies in skarn that total 406,219 st at an average grade of 0.189 percent $\mathrm{WO}_{3}$ (unpublished validity examination report by the BLM; Marcin and Horsburgh, 1983).

Although no resources were delineated at the New Klondike mine, results of the USBM sampling project, the resources developed on the patented group, and previous shipments from the general area preclude assigning only insignificant importance to metal concentrations at the margin of the granite. Because tungsten mineralization commonly occurs at the margins of intrusive stocks, a full evaluation of the study area would necessitate testing the entire periphery of the granite adjacent to and within the study area, which is a total distance of about $7 \mathrm{mi}$, to a reasonable mining depth. This would be a considerable exploration effort and far beyond the scope of this investigation.

Gold that occurs in quartz veins in the granite has been suggested as a source for the placer gold deposits in Amasa Valley (Smith and Smith, 1969, p. 38, 39). USBM sampling outside the study area has shown some gold to be present in the granite and associated skarns. Three samples assayed $0.20,0.17$, and $0.07 \mathrm{oz}$ gold/st at or near a fault contact between the granite and skarn; one sample assayed a trace of gold in the granite. A sample collected from an adit in the granite near its contact with limestone also showed a trace of gold. Four samples collected from a contact between the granite and a block of metamorphosed limestone on Pine Peak showed a trace of gold, and two samples assayed 0.16 and $0.03 \mathrm{oz}$ gold/st; however, this block of limestone does not extend into the study area (Lundby, 1987). Two samples collected from a small opencut in the contact zone at, or just within, the study area about $1 / 4 \mathrm{mi}$ east of Pine Peak assayed a trace and $0.04 \mathrm{oz}$ gold/st (Lundby, 1987). No gold resources were identified at or near the granite-limestone contact within the study area boundary.

\section{Brown Queen Mine Area}

Prospects and mines are located within the study area northeast of the Notch Peak intrusive, in the area of the Brown Queen mine (fig. 3, pl. 1; Lundby, 1987, pl. 1, fig. 1A). This area is within a northern extension of the Notch Peak metamorphic aureole (fig. 5; Hintze, 1974) that affects the Cambrian Marjum Formation, which is a silty limestone, and Weeks Limestone, which is a limestone with interbedded silty layers. The near-surface 
presence of granite in the Brown Queen mine area is indicated by a 1-ft-thick skarn zone that contains tungsten mineralization at the mine; by a $600 \times 2,700-\mathrm{ft}$, weakly to intensely iron stained and pyritized zone that contains minor tungsten and gold about $2,000 \mathrm{ft}$ north of the mine (Lundby, 1987, figs. 1A-E); and by a granite outcrop about $1 / 4$ mi south of the mine (USBM file data).

Workings in the area of the Brown Queen mine consist of seven adits (one caved) including the two at the Brown Queen mine, a 30-ft deep shaft, and a prospect pit (Lundby, 1987, fig. 1A). Thirty-seven samples were collected: two were minus-80-mesh stream-sediment samples, one was a panned concentrate sample, and 34 were chip samples taken from workings or outcrops.

Appreciable tungsten concentrations within the study area are in samples collected from a stratiform skarn mined in the Brown Queen mine. Samples from the northern adit contain $0.35-0.88$ percent $\mathrm{WO}_{3}$ (2,800-7,000 ppm W) and average 0.59 percent $\mathrm{WO}_{3}$ over a $0.9-\mathrm{ft}$ width. Samples from a $1.7-\mathrm{ft}$ width of the same zone mined on the southern adit contain 0.061.26 percent $\mathrm{WO}_{3}(640-10,000 \mathrm{ppm} \mathrm{W})$ and average 0.47 percent $\mathrm{WO}_{3}$ (Lundby, 1987, fig. 1E). The total resource estimate for the mine, based on a rock density of $9.2 \mathrm{ft}^{3} / \mathrm{st}$, is about $775 \mathrm{st}$ at an average of 0.47 percent $\mathrm{WO}_{3}$ (Lundby, 1987, fig. 1E). Additional work in the mine area, especially drilling, might increase the grade and tonnage of this resource estimate because the tungsten may be more concentrated at depth near the proposed, concealed granite contact.

Samples collected from, and adjacent to, the ironstained and pyritized zone north of the Brown Queen mine contain minor amounts of gold and silver. A dump sample of gossan and coarse-grained calcite from a 30-ft-deep shaft east of the pyritized zone assayed $0.07 \mathrm{oz}$ gold/st (Lundby, 1987, fig. 1A, table 1); three samples from near the portal of an adit within the pyritized zone assayed $0.07,0.06$, and $0.02 \mathrm{oz}$ gold/st and $0.1,1.5$, and $0.3 \mathrm{oz}$ silver/st, respectively (Lundby, 1987, fig. 1C). Although no resources can be identified at these occurrences, results from the USBM sampling indicate that additional exploration work in the zone of pyritization might be justified to determine whether significant resources of gold and (or) silver are present.

\section{Sawtooth Canyon Area}

Seventeen samples were collected from an adit, two shafts, three opencuts, and an outcrop along the south side of Sawtooth Canyon (Lundby, 1987, pl. 1) at the White Lady prospect (fig. 3 ) about 3 mi southeast of the nearest mapped exposure of the granite at Notch Peak.
Most of the rock in the area is limestone, although a diabase dike is exposed at one of the opencuts.

Two samples taken from an intensely brecciated fault zone that is exposed in the adit assayed traces of gold. Tungsten concentrations were very low; the highest value was $16 \mathrm{ppm}$ ( 0.0016 percent $\mathrm{W}, 0.0020$ percent $\mathrm{WO}_{3}$ ). No resource was delineated in the Sawtooth Canyon area.

\section{Industrial Rocks}

Construction materials are common in the area. Limestone of similar age and composition to that found in the study area is common throughout the region. Similarly, sand and gravel found along the flanks of the House Range are ubiquitous in the region. Therefore, development of limestone and sand and gravel that occur within the study area seems unlikely in the foreseeable future.

\section{Conclusions}

The granite at Notch Peak appears to be the source for the mineralizing process in and adjacent to the study area, as evidenced by the contact metamorphism, metasomatism, and associated tungsten-gold-molybdenum occurrences. A tungsten resource and a nearby gold occurrence in Cambrian limestone are in the Brown Queen mine area. A resource of $775 \mathrm{st}$ at an average of 0.47 percent $\mathrm{WO}_{3}$ was defined at the Brown Queen mine; additional exploration in the area, especially drilling, probably would increase the tonnage and possibly the grade of this resource.

In and adjacent to the study area, skarns that contain scheelite occur at the limestone-granite contact, molybdenum-copper-tungsten occurrences are near the west boundary, tungsten resources occur near the east boundary at the New Klondike mine, minor gold occurrences are in the granite and at its margins adjacent to the study area, and placer gold deposits are being mined in Amasa Valley. Although no resources have been delineated along the limestone-granite contact within the study area, evidence indicates that considerable exploration work is necessary to fully evaluate this zone of possible mineral deposition.

Limestone and sand and gravel occur within the study area, but prevalence of these materials throughout the region precludes their development in the foreseeable future. 


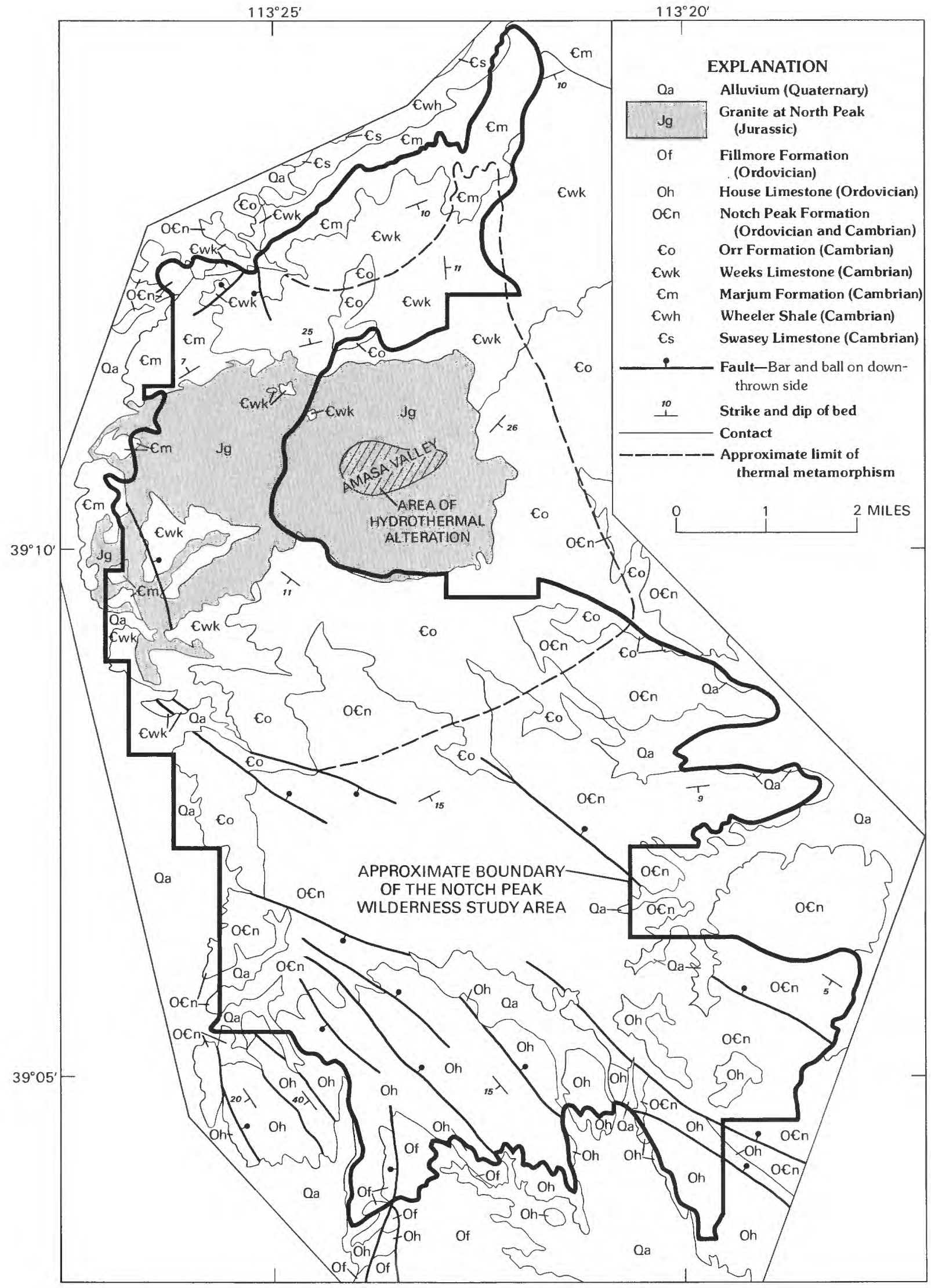

Figure 5. Simplified geologic map of the Notch Peak Wilderness Study Area and vicinity (modified from Hintze, 1974). 


\section{ASSESSMENT OF POTENTIAL FOR UNDISCOVERED RESOURCES}

\author{
By Douglas B. Stoeser, \\ David L. Campbell, Victor Labson, \\ David R. Zimbelman, \\ Melvin H. Podwysocki, \\ David W. Brickey, Joseph S. Duval, and \\ Kenneth L. Cook ${ }^{3}$ \\ U.S. Geological Survey
}

\section{Geology}

\section{Geologic Setting}

The bedrock geology of the study area consists of seven Cambrian and Ordovician sedimentary rock formations that are intruded by a Jurassic granite, the Notch Peak intrusive (pl. 1). The House Range is bounded by a concealed range-front fault along its western margin. Internally the structure of the range is simple, and the central House Range consists of sedimentary rocks that typically dip from $5^{\circ}$ to $20^{\circ}$ southward, except near the granite, which appears to have gently domed the sedimentary rocks (Gehman, 1958). No folds or thrust faults have been mapped within the central House Range (Hintze, 1974). A few high-angle faults have been mapped in the northern part of the study area, and numerous high-angle normal faults occur in the southern part of the study area (pl. 1). More detailed information on aspects of the structural geology of the study area is presented in the geophysics section of this report.

\section{Sedimentary Rocks}

The sedimentary rocks exposed within the study area were deposited as marine sediments along a continental margin that existed during Cambrian and Ordovician time (Hintze, 1973; Rees, 1986). The rocks of the study area were subsequently involved in two major episodes of regional deformation. The first episode was during the late Mesozoic when the rocks of the continental margin were thrust eastward over the continental interior to form the Sevier orogenic belt which extended from Montana and Idaho to New Mexico and Arizona (Armstrong, 1968; Hintze, 1973). Several low-angle thrust-fault planes or detachment surfaces that underlie

3University of Utah. the House Range are discussed in the geophysics section of this report. The second episode was Tertiary regional extension which formed the Basin and Range province. The province is a broad belt of north-south elongate crustal blocks that consist of alternating upthrown blocks which form mountain ranges and downthrown blocks which form deep to shallow intermontane sedimentary basins (Eaton, 1982). The House Range and its adjacent basins are typical of the province.

Sedimentary rock formations exposed within the study area are, from oldest to youngest, the Cambrian Wheeler Shale, Marjum Formation, Weeks Limestone, and Orr Formation, Cambrian and Ordovician Notch Peak Formation, and Ordovician House Limestone and Fillmore Formation. The Cambrian rocks of the House Range represent one of the best exposed and most complete sections of Cambrian rocks in North America and have been intensively studied by paleontologists and stratigraphers since the early part of this century (Walcott, 1908; Palmer, 1971; Hintze and Robison, 1987).

The Middle Cambrian Wheeler Shale, which only crops out in the northernmost part of the study area, consists of dark- to medium-gray calcareous shale and thin-bedded shaly limestone (Robison, 1964b; Hintze, 1974). About $10 \mathrm{mi}$ northeast of the study area, the Wheeler Shale provides one of the premier collecting localities for Cambrian fossils in the United States. Trilobites are found in abundance along with many other types of fossils (Robison, 1964a), including remains of soft-bodied animals, occurrences of which are extremely rare in the early Paleozoic fossil record (Conway and Robison, 1986). The well-preserved trilobites are quarried and sold to collectors and the general public (Lindsey and others, 1989). One small fossil quarry in the Marjum Formation is located in the northernmost part of the study area (fig. 3 ).

The Middle Cambrian Marjum Formation in the northern part of the study area is about $1,400 \mathrm{ft}$ thick and consists of thin-bedded silty limestone, interbedded with shale and mudstone (Robison, 1964b; Hintze, 1974).

The Middle and Upper Cambrian Weeks Limestone in the study area is about $1,200 \mathrm{ft}$ thick and composed of limestone and thin interbeds of silty limestone (Robison, 1964b; Hintze, 1974).

In the central House Range, the Upper Cambrian Orr Formation is divided into five members (pl. 1) (Hintze, 1974; Hintze and Palmer, 1976). These are, from oldest to youngest, the Big Horse Limestone Member (720 ft), the Candland Shale Member (210 $270 \mathrm{ft}$ ), the Johns Wash Limestone Member (140$200 \mathrm{ft}$ ), the Corset Spring Shale Member (100-110 ft), and the Sneakover Limestone Member (110-155 ft). The total thickness of the Orr Formation in the study area is about $1,300-1,400 \mathrm{ft}$. 
The Upper Cambrian and Lower Ordovician Notch Peak Formation is divided into three members (pl. 1) (Hintze, 1974; Hintze and others, 1987). These are, from oldest to youngest, the Hellnmaria Member $(1,200 \mathrm{ft})$ which consists of thick-bedded to massive limestone; the Red Tops Member ( $110 \mathrm{ft}$ ) which consists of thin-bedded bioclastic lime grainstone (calcarenite); and the Lava Dam Member (380 ft) which consists of massive limestone, stromatolitic limestone, and cherty limestone.

The youngest Paleozoic rock units exposed within the study area are the House Limestone and Fillmore Formation of the Ordovican Pogonip Group (Hintze, 1974). Both crop out only in the southernmost part of the study area. The House Limestone is about $500 \mathrm{ft}$ thick and is composed of massive, silty, sparsely cherty limestone. Only about $1,000 \mathrm{ft}$ of the lower part of the Fillmore Formation occurs in the study area (pl. 1). It consists of medium-gray to yellowish-gray limestone, limy shale and siltstone, and thin- to thick-bedded intraformational limy conglomerate (Powell, 1959; Hintze, 1974).

\section{Notch Peak Intrusive}

The Notch Peak intrusive, which is in the northcentral part of the study area, is roughly rectangular in shape, elongate along an east-west axis, with approximate dimensions of $2 \frac{1}{2} \times 4^{1} \frac{1}{2} \mathrm{mi}$. Only the western half of the granite is located within the study area. The granite intrudes the Marjum Formation, the Weeks Limestone, and the Big Horse Limestone Member of the Orr Formation. The granite at Notch Peak has been studied by Crawford and Buranek (1941), Gehman (1958), Powell (1959), Hanks (1962), Nabelek (1983, 1986), and Nabelek and others $(1983,1984)$. Paleomagnetic data for the granite are available in Gillett and others (1982). A number of radiometric ages are available for the Notch Peak intrusive: a lead-alpha age of 193 million years (m.y.) by Odekirk (1963), a K-Ar biotite-hornblende age of $143 \pm 3$ m.y. by Armstrong and Suppe (1973), an ${ }^{39} \mathrm{Ar}-40 \mathrm{Ar}$ biotite age of 165 m.y. by Nabelek (1983, p. 234), and a U-Pb zircon age of $163 \pm 3$ m.y. by Lee and others (1986). The Notch Peak intrusive is assumed to be Jurassic in age.

The form of the Notch Peak pluton has been interpreted as a laccolith (intrusive body with a flat bottom) by Crawford and Buranek (1941) and Smith and Smith (1969) and as a stock (intrusive body that extends to considerable depth) by Powell (1959), Hanks (1962), and Nabelek (1983). As demonstrated in the geophysics section of this report, there is geophysical evidence to support the laccolith interpretation. Parts of the roof of the pluton are still in place and consist of limestone capping the granite in the western part of the intrusion (pl. 1). Based on detailed study, Nabelek (1983) estimated that the upper part of the Notch Peak pluton was emplaced at a depth of about $15,000 \mathrm{ft}$.

Within the study area, the bulk of the granite consists of a homogeneous porphyritic biotite granite. The granite contains 20-30 percent phenocrysts which consist of $1 / 2-1$-in. pink perthite and less than $1 / 2$-in. quartz (Gehman, 1958; Nabelek, 1983). The granite is potassium-rich, and modal analyses by Gehman (1958), Powell (1959), and Hanks (1962) show 20-28 percent quartz, 14-32 percent oligoclase (plagioclase), 308 percent orthoclase, 11-28 percent two-phase feldspar (perthite), 3-5 percent biotite, and trace amounts of sphene, apatite, magnetite, and zircon.

Aplite dikes, which are mostly less than $3 \mathrm{ft}$ thick but as much as $50 \mathrm{ft}$ thick, occur throughout the granite and along the margins where the dikes intrude the sedimentary host rock. Granitic granophyre (fine-grained granite) dikes and sills also occur at many places along the contact. Nabelek (1986) studied the petrology of several of the granophyres and aplites. The deepest exposures of the granite are at the base of the west face, where abundant sills of biotite granite, aplite, granophyre, and minor pegmatite intrude the Marjum Formation. In particular, near the base of the west face several sills of granite more than $100 \mathrm{ft}$ thick extend southward from the main body of granite for more than $1 \mathrm{mi}$ (pl. 1). Crawford and Buranek (1941) reported amazonite (green potassic feldspar) from several pegmatite sills on the west face near Painter Spring (fig. 3). The aplite dikes are associated with tungsten, molybdenum, and minor copper mineralization along the entire west face of the Notch Peak intrusive (Kerr, 1946; Smith and Smith, 1969; Petersen, 1976). Tungsten occurs as scheelite, and molybdenum occurs as molybdenite; both minerals occur in the aplite dikes and in skarn adjacent to the dikes. Molybdenite, together with chalcopyrite, is also found in sparse quartz veins associated with the aplite dikes (Smith and Smith, 1969; Petersen, 1976).

\section{Metamorphic Aureole and Mineralization}

The metamorphic aureole of the Notch Peak intrusive extends as far as $2 \frac{1}{2} \mathrm{mi}$ from the exposed granite contact (Hintze, 1974) (pl. 1). A general study of the metamorphic aureole is presented in Gehman (1958). Detailed petrologic, isotopic, and paleomagnetic studies for the portion of the aureole that includes the Big Horse Limestone Member of the Orr Formation are presented in Gillett and others (1982), Hover Granath and others (1983), Nabelek and others (1984), and Labotka and others (1988). Gehman (1958) recognized three main zones within the metamorphic aureole: (1) a zone of early thermal recrystallization of the limestone to marble and the formation of a biotite-anorthite contact meta- 
morphic rock from the argillaceous parts of the sedimentary host rocks, (2) an irregular zone as much as $1 / 2 \mathrm{mi}$ wide of banded diopside-idocrase and calcitegarnet (grossularite) rock, and (3) a zone of ironsilica replacement along the granite contact where local scheelite-bearing andradite-garnet-diopside skarns formed. The Notch Peak tungsten skarns are typical of those associated with felsic plutons world-wide (Kwak, 1987).

The metamorphic aureole around the granite is fairly symmetrical except for an elongated part of the aureole that extends to the north-northeast (pl. 1). The cause of this extension is not clear. Hintze (1974) assumed that an arm of the granite extends beneath the surface northward from the main body of the pluton, whereas Petersen (1976), on the basis of a magnetometer survey, hypothesized a shallow granite sill beneath the aureole extension. The occurrence of several tungsten prospects and the Brown Queen tungsten mine, the metamorphism, a distinct change in the strike and dip of the sedimentary rocks within the extension relative to those of the general area, and an extension of the magnetic anomaly caused by the Notch Peak pluton (see geophysics section of this report) strongly suggest that shallow intrusive rock underlies the aureole extension.

Skarn has been found at many places along the margin of the pluton and replaces carbonates of all three formations that are intruded by the granite (Petersen, 1976). The skarn bodies are lensoid to irregular in shape and range from less than $1 \mathrm{ft}$ to tens of feet in length. Whenever tested with an ultraviolet lamp, the skarns contain scheelite. In addition to garnet, diopside, and scheelite, the skarns may also contain quartz, calcite, orthoclase, amphibole, epidote, and, at some locations on the west face, pyrite, chalcopyrite, and molybdenite (Petersen, 1976). Scheelite from the skarn along the exposed margin of the pluton is molybdenum-rich as indicated by yellow fluorescence under ultraviolet light, whereas scheelite at the Brown Queen mine is molybdenum-poor as indicated by blue-white fluorescence.

Vein and replacement tungsten mineralization, which is related to low-temperature hydrothermal alteration, occurs in the area of the Brown Queen mine. An area of bleached Marjum Formation limestone extends northward from the mine for about $3 / 4 \mathrm{mi}$. Within this area are numerous eastward-striking, steeply dipping calcite and quartz veins. Most of the veining consists of coarse-grained, white-to-black calcite veins that are mostly 6 in. or less thick, although a few are as much as $3 \mathrm{ft}$ thick. Sparse quartz veins associated with the calcite veins locally contain scheelite. At the Brown Queen mine, the scheelite occurs in several siliceous stratiform replacement bodies after layers within the Marjum Formation. A thin section of rock from the main ore zone at the Brown Queen mine shows that the zones are distinct from skarn that is found along the granite contact and consist mainly of fine-grained quartz, with disseminated fine-grained euhedral scheelite crystals and altered amphibole. The scheelite from the Brown Queen mine and the quartz veins, unlike scheelite from the Notch Peak skarns, is molybdenum-poor as shown by its blue-white fluorescence.

In addition to the tungsten and molybdenum mineralization, the Notch Peak intrusive also has associated gold mineralization. As mentioned earlier, gold is being produced from small placers in Amasa Valley within the eastern part of the granite. The source of the gold is apparently an area of weakly altered granite that contains small quartz veins (fig. 5) (Smith and Smith, 1969). This area of altered granite and veining is restricted to the Amasa Valley and does not extend into the study area. In addition, as noted previously in this report, anomalous amounts of gold were detected geochemically in some of the skarns associated with the granite and anomalous amounts of gold and silver were found in mineralized rock from the area of the Brown Queen Mine.

\section{Geochemistry}

\section{Introduction}

A reconnaissance geochemical survey was conducted in the study area in 1986. Minus-80-mesh streamsediment samples, heavy-mineral concentrates derived from stream-sediment samples (herein referred to simply as concentrates), and rock samples were collected for evaluation of possible indicators of alteration and (or) mineralization. Chemical analysis of sediments provides information that helps identify those drainage basins that contain high concentrations of elements, some of which may be related to mineral occurrences. Stream-sediment samples and concentrates were collected from active alluvium in first-order streams (unbranched) and second-order streams (below the junction of two firstorder streams) as shown on figure 6 . In addition, streamsediment samples collected from the study area during the NURE program (Jones, 1979) were split into two fractions; one fraction was simply reanalyzed by the USGS as a stream-sediment sample, and the other fraction was processed as a heavy-mineral-concentrate sample and subsequently analyzed by the USGS. Rock samples were collected from both in and near the study area. Samples of rock that appeared to be unaltered were taken to provide information on geochemical background values. Rock samples from mines, prospects, and altered areas were taken to determine suites of elements associated with mineralization and alteration (table 2). Analytical data and a description of the sampling and 
Table 1. Summary of geochemical anomalies for selected elements in heavy-mineral concentrates of stream-sediment samples, Notch Peak Wilderness Study Area, Utah

[Selected elements and associated minimum values (shown in parentheses) that are considered anomalous include: $\mathrm{Au}(20), \mathrm{Ag}(5)$, As (500), $\mathrm{Be}$ (5), Bi (20), Cd (50), Cu (500), Mo (20), Pb (500), Sb (200), Sn (20), W (100), and Zn (500). $>$, greater than. Sample localities shown in figure 6]

\begin{tabular}{ll}
\hline Sample No. & \multicolumn{1}{c}{\begin{tabular}{c}
\multicolumn{1}{c}{ Anomalous elements } \\
(in parts per million)
\end{tabular}} \\
\hline $\mathrm{C} 004$ & W (200), Ag (5) \\
$\mathrm{C} 007$ & Mo (1500), W (10,000), Bi (700) \\
$\mathrm{C} 010$ & Mo (1000), W (7000), Bi (100) \\
$\mathrm{C} 011$ & Mo (50), W (1500), Bi (20) \\
$\mathrm{C} 012$ & Mo (30), Sn (>2000), Pb (500) \\
& \\
$\mathrm{C} 015$ & Mo (50, W (500), Zn (500) \\
$\mathrm{C} 016$ & Mo (200), W (2000) \\
$\mathrm{C} 017$ & Mo (700), W (700) \\
$\mathrm{C} 018$ & Mo (500), W (500) \\
$\mathrm{C} 019$ & Mo (20), W (100) \\
$\mathrm{C} 020$ & Bi (30), Sn (150), Pb (1500) \\
$\mathrm{C} 021$ & Mo (30), W (10,000), Sn (500) \\
$\mathrm{C} 023$ & W (2000) \\
$\mathrm{C} 028$ & Mo (500), W (20,000), Bi (70) \\
$\mathrm{C} 030$ & Mo (50), W (700) \\
\hline
\end{tabular}

analytical techniques are available from David R. Zimbelman, U.S. Geological Survey, MS 973, Box 25046, Denver Federal Center, Denver, CO 80225.

\section{Summary of Results}

Analyses of the nonmagnetic fraction of heavymineral-concentrate (referred to as "concentrate") and rock samples were very useful for the evaluation of the study area on a reconnaissance basis. The bulk streamsediment samples showed no significant geochemical anomalies and are not discussed further. Most of the rock-forming silicates and organic material are selectively removed during the selective concentration of minerals that may be related to ore-forming processes. Minerals that are concentrated include sulfide, carbonate, sulfate, tungstate, and oxide minerals such as pyrite $\left(\mathrm{FeS}_{2}\right)$, galena $(\mathrm{PbS})$, molybdenite $\left(\mathrm{MoS}_{2}\right)$, sphalerite $(\mathrm{ZnS})$, stibnite $\left(\mathrm{Sb}_{2} \mathrm{~S}_{3}\right)$, barite $\left(\mathrm{BaSO}_{4}\right)$, scheelite $\left(\mathrm{CaWO}_{4}\right)$, cerussite $\left(\mathrm{PbCO}_{3}\right)$, smithsonite $\left(\mathrm{ZnCO}_{3}\right)$, cassiterite $\left(\mathrm{SnO}_{2}\right)$, and native gold. Therefore analysis of concentrate samples permits determination of some elements that are not easily detected in bulk streamsediment samples.

Threshold values (highest values not considered anomalous) were determined by inspection of frequency distribution histograms for each element in the concentrate and rock data sets and are listed in tables 1 and 2 , respectively.

Concentrate samples that contain anomalous amounts of selected elements are listed in table 1, and their location is shown in figure 6 . The concentrate anomalies generally occur in the northern half of the study area, especially from streams that drain the area of the Notch Peak granite and its metamorphic aureole. Samples from the northern half of the study area commonly contain anomalous amounts of tungsten and molybdenum and locally contain anomalous amounts of silver, bismuth, tin, lead, or zinc. The elements that occur in anomalous amounts in concentrate samples most frequently, tungsten and molybdenum, probably originated from elevated concentrations of these elements in samples of skarn, vein, and altered granite. The source(s) of the elevated concentrations of silver, bismuth, tin, lead, and zinc is not as clear. Locally, anomalous amounts of some of these elements, especially bismuth and tin, probably originated from areas of skarn, vein, or altered granite. However, there is little evidence to suggest that elevated amounts of the other elements occur in these rock types in the study area, and the source of these anomalies, therefore, is uncertain.

Many of the rock samples that were collected north or west of Sawtooth Canyon contain geochemically anomalous amounts of one or more of the following elements: molybdenum, tungsten, beryllium, tin, gold, arsenic, copper, bismuth, and barium (fig. 7). The geochemically anomalous rock samples are listed in table 2 along with a brief description of the macroscopic characteristics of the samples. Many of the rock samples listed in table 2 were collected just outside the study area boundary in order to characterize the geochemical signature of the known types of mineralization in the vicinity of the Notch Peak intrusive.

Skarn mineralization occurs both at the contact of igneous rocks with favorable, carbonate-bearing sedimentary rocks and, especially in the Bird Canyon area, in bleached and recrystallized, carbonate-bearing sedimentary rocks away from any obvious igneous rock outcrop. Skarn mineralization typically contains anomalous amounts of molybdenum, tungsten, tin, and beryllium, and locally contains anomalous amounts of barium and bismuth (table 2).

Altered rock (described in table 2 as carbonatereplacement rock) also occurs in the Bird Canyon area and consists of brown, frothy to massive, very fine grained silica and various iron oxide minerals which replace carbonate rocks. This altered rock is commonly anomalous in copper, tungsten, molybdenum, and, locally, barium (table 2). 
Table 2. Summary of geochemical anomalies for selected elements in rock samples, Notch Peak Wilderness Study Area, Utah

[Selected elements and associated minimum values (shown in parentheses) that are considered anomalous include: $\mathrm{Au}(0.05), \mathrm{Ag}(5), \mathrm{As}(200)$, $\mathrm{Ba}(5000), \mathrm{Be}(5), \mathrm{Bi}(10), \mathrm{Cd}(20), \mathrm{Cu}(500)$, Mo (20), Pb (500), Sb (100), Sn (10), W (50), and Zn (500). Sample localities shown in figure 7]

\begin{tabular}{|c|c|c|}
\hline $\begin{array}{l}\text { Sample } \\
\text { No. }\end{array}$ & $\begin{array}{l}\text { Anomalous elements } \\
\text { (in parts per million) }\end{array}$ & Description \\
\hline 0063 & Mo (100), W (3000) & Granite; contains thin, white quartz veinlets. \\
\hline 0065 & Mo (20), W (200), Au (0.05) & $\begin{array}{l}\text { Granite; argillically altered; contains many quartz veins as much } \\
\text { as } 1 \text { in. thick and iron oxide staining along fractures. }\end{array}$ \\
\hline 0068 & $\mathrm{~W}(100), \mathrm{Au}(0.05)$ & Granite; argillically altered granite. \\
\hline 1080 & Mo (30), W (1000) & Granite; contains quartz veinlets and iron oxide staining. \\
\hline 1084 & Mo (50), $\mathrm{Be}(7)$ & Granite; argillically altered. \\
\hline 1085 & Mo (20), W (100), As (200) & Granite; adjacent to large quartz vein. \\
\hline 1086 & Mo (50), W (1500) & $\begin{array}{l}\text { Granite; argillically altered; contains quartz veins and iron } \\
\text { oxide staining. }\end{array}$ \\
\hline 1087 & Mo (30), W (1000) & Quartz vein; stained with iron oxide minerals. \\
\hline 1109B & Mo (200), W (3000), Be (5), Sn (70) & Skarn; contains garnet and quartz. \\
\hline $1109 \mathrm{C}$ & Mo (500), W (2000), Be (20) & Limestone; contains epidote. \\
\hline 1109D & $\mathrm{Be}(10), \mathrm{Sn}(10)$ & Fault gouge. \\
\hline $1109 \mathrm{E}$ & Mo (500), W (3000), Be (10), Sn (100) & Skarn; contains garnet and quartz. \\
\hline $5002 \mathrm{~A}$ & Mo (100), W (2000), Sn (100) & Skarn; massive garnetite. \\
\hline $5002 B$ & Mo (50), W (500), Be (5) & $\begin{array}{l}\text { Quartz vein; clear to white, very fine grained to fine-grained; } \\
\text { contains vugs lined with iron oxide minerals. }\end{array}$ \\
\hline $5002 \mathrm{C}$ & $\begin{array}{l}\text { Mo }(50), \mathrm{W}(5000), \mathrm{Be}(50), \mathrm{Au}(0.40) \\
\mathrm{Cu}(3000), \mathrm{Bi}(50)\end{array}$ & $\begin{array}{l}\text { Quartz vein; vuggy, heavily stained brown with iron oxide } \\
\text { minerals. }\end{array}$ \\
\hline $5003 \mathrm{~A}$ & Mo (200), W (2000), Be (20), Sn (50) & $\begin{array}{l}\text { Hornfels; gray, vuggy, very fine grained; stained with iron oxide } \\
\text { minerals. }\end{array}$ \\
\hline 5004 & $\mathrm{~W}(50), \mathrm{Be}(7)$ & $\begin{array}{l}\text { Quartz vein; gray, }<1 \mathrm{~mm} \text { to } 2 \mathrm{~cm} \text { wide; numerous veins and } \\
\text { veinlets cut altered granite. }\end{array}$ \\
\hline 5225B & $\mathrm{W}(200), \mathrm{Cu}(2000)$ & $\begin{array}{l}\text { Carbonate-replacement; yellowish-brown to dark-brown; } \\
\text { decomposed, heavily oxidized material along narrow fracture } \\
\text { zone. }\end{array}$ \\
\hline $5226 \mathrm{~B}$ & Mo (20), W (200), Cu (5000) & $\begin{array}{l}\text { Carbonate replacement; dark- to orangish-brown, frothy; } \\
\text { mostly hematite(?); occurs in center of calcite vein. }\end{array}$ \\
\hline $5226 \mathrm{C}$ & $\mathrm{Cu}(5000)$ & $\begin{array}{l}\text { Carbonate replacement; brown, decomposed, iron oxide } \\
\text { material. }\end{array}$ \\
\hline $5227 \mathrm{~A}$ & $\mathrm{Ba}(>5000)$ & Marble; grayish-white, very coarse grained, granular. \\
\hline 5227B & Mo $(200), \mathrm{W}(>10,000), \mathrm{Ba}(>5000)$ & $\begin{array}{l}\text { Carbonate replacement; very light brown, dense, massive } \\
\text { silicified zone. }\end{array}$ \\
\hline $5227 \mathrm{C}$ & Mo (2000), W (700), Bi (10), Ba $(>5000)$ & Carbonate replacement; medium brown, dense, silicified zone. \\
\hline $5227 \mathrm{D}$ & Mio (20), W (2000), Ba $(>5000)$ & $\begin{array}{l}\text { Skarn; red, very fine grained, massive; contains quartz and } \\
\text { garnet(?). }\end{array}$ \\
\hline $5228 \mathrm{~A}$ & $\mathrm{Be}(5)$ & Granite; gray, equigranular; no obvious alteration. \\
\hline
\end{tabular}


Table 2. Summary of geochemical anomalies for selected elements in rock samples, Notch Peak Wilderness Study Area, Utah-Continued

\begin{tabular}{|c|c|c|}
\hline $\begin{array}{l}\text { Sample } \\
\text { No. }\end{array}$ & $\begin{array}{l}\text { Anomalous elements } \\
\text { (in parts per million) }\end{array}$ & Description \\
\hline $5229 \mathrm{~A}$ & $\mathrm{Mo}(20), \mathrm{Cu}(700)$ & $\begin{array}{l}\text { Carbonate replacement; brown, decomposed, clay and iron } \\
\text { oxide material. }\end{array}$ \\
\hline $5229 \mathrm{~B}$ & Mo (300), W (500), Be (10) Sn (100) & $\begin{array}{l}\text { Skarn; dark-brown, very coarse grained; contains garnet and } \\
\text { quartz. }\end{array}$ \\
\hline $5229 \mathrm{C}$ & W (100), Sn (10) & $\begin{array}{l}\text { Granite; yellowish-brown, very coarse grained; laced with } \\
\text { fractures, quartz veinlets, and iron oxide minerals. }\end{array}$ \\
\hline $5229 \mathrm{D}$ & Mo (50), W (100), Be (5) & $\begin{array}{l}\text { Quartz vein; gray, very fine grained; contains fragments of } \\
\text { granite. }\end{array}$ \\
\hline 5304B & $\mathrm{Be}(5)$ & Limestone; gray, brecciated; contains iron oxide staining. \\
\hline $5310 \mathrm{~A}$ & Mo (100), W (1000), Be (10), Sn (500) & $\begin{array}{l}\text { Skarn; dark-reddish-brown, fine- to coarse-grained; contains } \\
\text { garnet and quartz. }\end{array}$ \\
\hline $5310 \mathrm{~B}$ & Mo (200), W (1500), Be (7), Sn (700) & $\begin{array}{l}\text { Skarn; dark-reddish-brown to gray, banded, fine- to coarse- } \\
\text { grained; contains garnet and quartz. }\end{array}$ \\
\hline $5310 \mathrm{C}$ & $\mathrm{Be}(7)$ & Granite; gray, coarse-grained, relatively fresh looking. \\
\hline $5315 \mathrm{~A}$ & Mo $(200)$, W $(2000)$, Sn $(200)$ & $\begin{array}{l}\text { Skarn; reddish-brown, fine- to very coarse grained; contains } \\
\text { garnet, quartz, and pyrite. }\end{array}$ \\
\hline 5315B & Mo (100), W (500), Sn (500) & $\begin{array}{l}\text { Skarn; reddish-brown, fine to very coarse grained; contains } \\
\text { garnet, quartz, and pyrite. }\end{array}$ \\
\hline 5315C & Mo $(200), W(5000), \operatorname{Sn}(300)$ & $\begin{array}{l}\text { Skarn; reddish-brown, fine to very coarse grained; contains } \\
\text { garnet and quartz. }\end{array}$ \\
\hline $5315 \mathrm{~F}$ & $\mathrm{Be}(10)$ & Aplite dike; white, very fine grained; $15-20 \mathrm{~cm}$ wide. \\
\hline $5315 \mathrm{H}$ & Mo (50), W (1000), Sn (200), Bi (10) & $\begin{array}{l}\text { Skarn; brown, fine to very coarse grained; contains chlorite, } \\
\text { garnet, and hematite. }\end{array}$ \\
\hline 5317 & Mo (30), W (100), Be (50), As (1500) & $\begin{array}{l}\text { Jasperoid; brown, flinty; contains quartz and iron oxide } \\
\text { minerals; occurs between sills of granite. }\end{array}$ \\
\hline $5318 \mathrm{~A}$ & Mo (200), Be (20), Cu (500), Au (0.05) & $\begin{array}{l}\text { Vein; brown, vuggy to coarse-grained; contains fragments of } \\
\text { granite, quartz, pyrite, chalcopyrite, molybdenite, and iron } \\
\text { oxide minerals. }\end{array}$ \\
\hline 5318B & Mo (150), Be (10) & $\begin{array}{l}\text { Granite; gray, coarse-grained, equigranular; contains quartz, } \\
\text { potassium feldspar, biotite, and disseminated molybdenite } \\
\text { and pyrite. }\end{array}$ \\
\hline $5318 \mathrm{C}$ & Mo (100), W (100), Be (30), Au (0.10), Cu (3000) & $\begin{array}{l}\text { Granite; as in above sample, but contains more sulfide } \\
\text { minerals, including chalcopyrite. }\end{array}$ \\
\hline 5318D & Mo (20), W (100), Be (20), Sn (200) & $\begin{array}{l}\text { Skarn; reddish-brown, fine- to coarse-grained; contains garnet, } \\
\text { quartz, pyrite, and amphibole minerals. }\end{array}$ \\
\hline $5318 \mathrm{E}$ & Mo (100), W 500), Be (30) & Skarn; as in above sample, but contains more pyrite. \\
\hline $5318 \mathrm{~F}$ & Mo (100), W (2000), Be (20), Sn (300) & Skarn; reddish-brown, very coarse grained, massive garnetite. \\
\hline 5319 & Mo (50) & $\begin{array}{l}\text { Granite; brown, coarse-grained, equigranular, heavily stained } \\
\text { with iron oxide minerals. }\end{array}$ \\
\hline 5320 & $\mathrm{Be}(10)$ & $\begin{array}{l}\text { Granite; brown, coarse-grained, equigranular; contains } 1-2-\mathrm{cm} \\
\text { quartz veins. }\end{array}$ \\
\hline
\end{tabular}




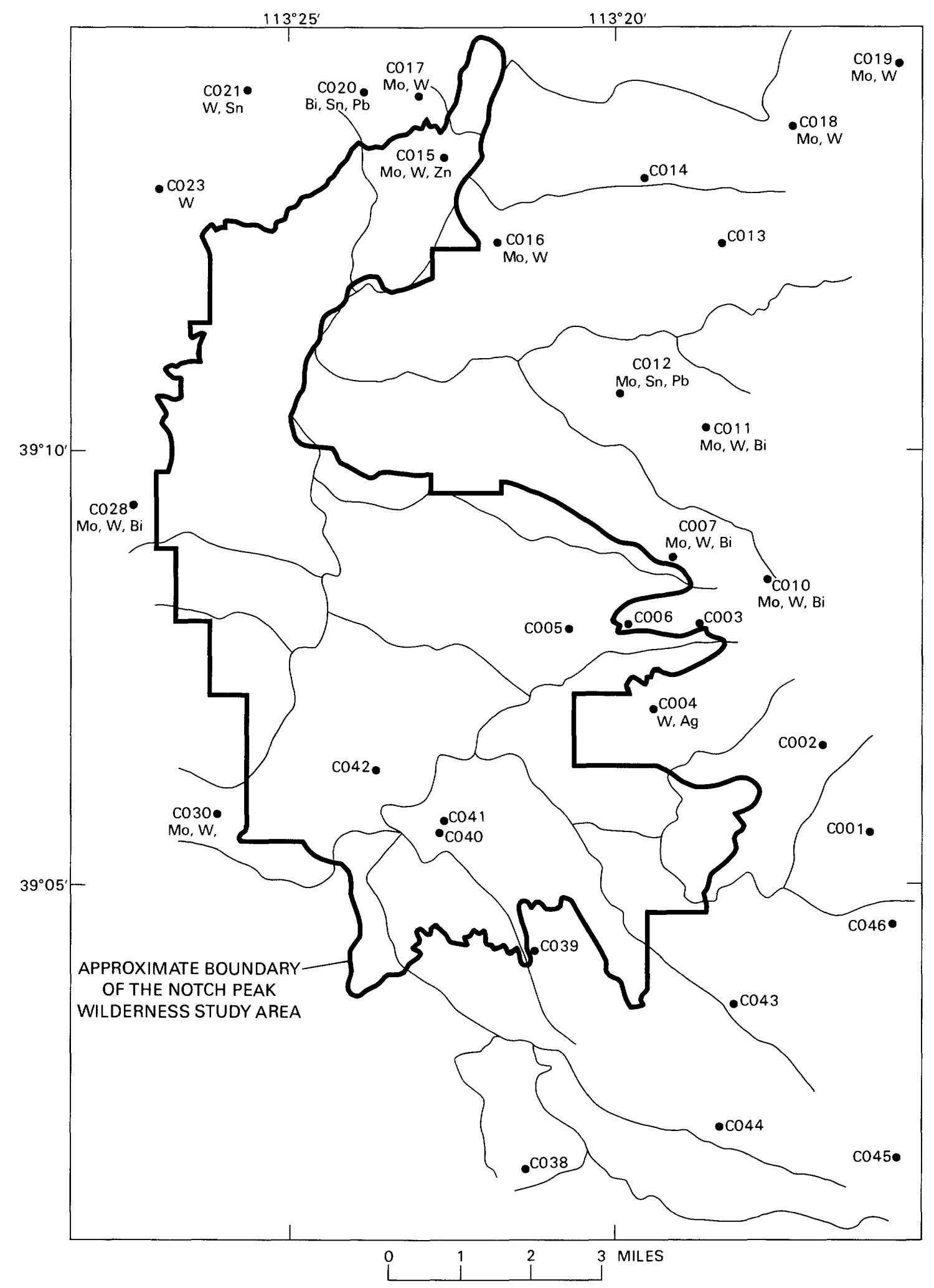

Figure 6. Location of stream-sediment sample sites, drainage basins, and anomalous elements in heavy-mineral-concentrate samples in and near the Notch Peak Wilderness Study Area. Summary of geochemical anomalies for selected elements in heavy-mineral-concentrate samples is shown in table 1. 


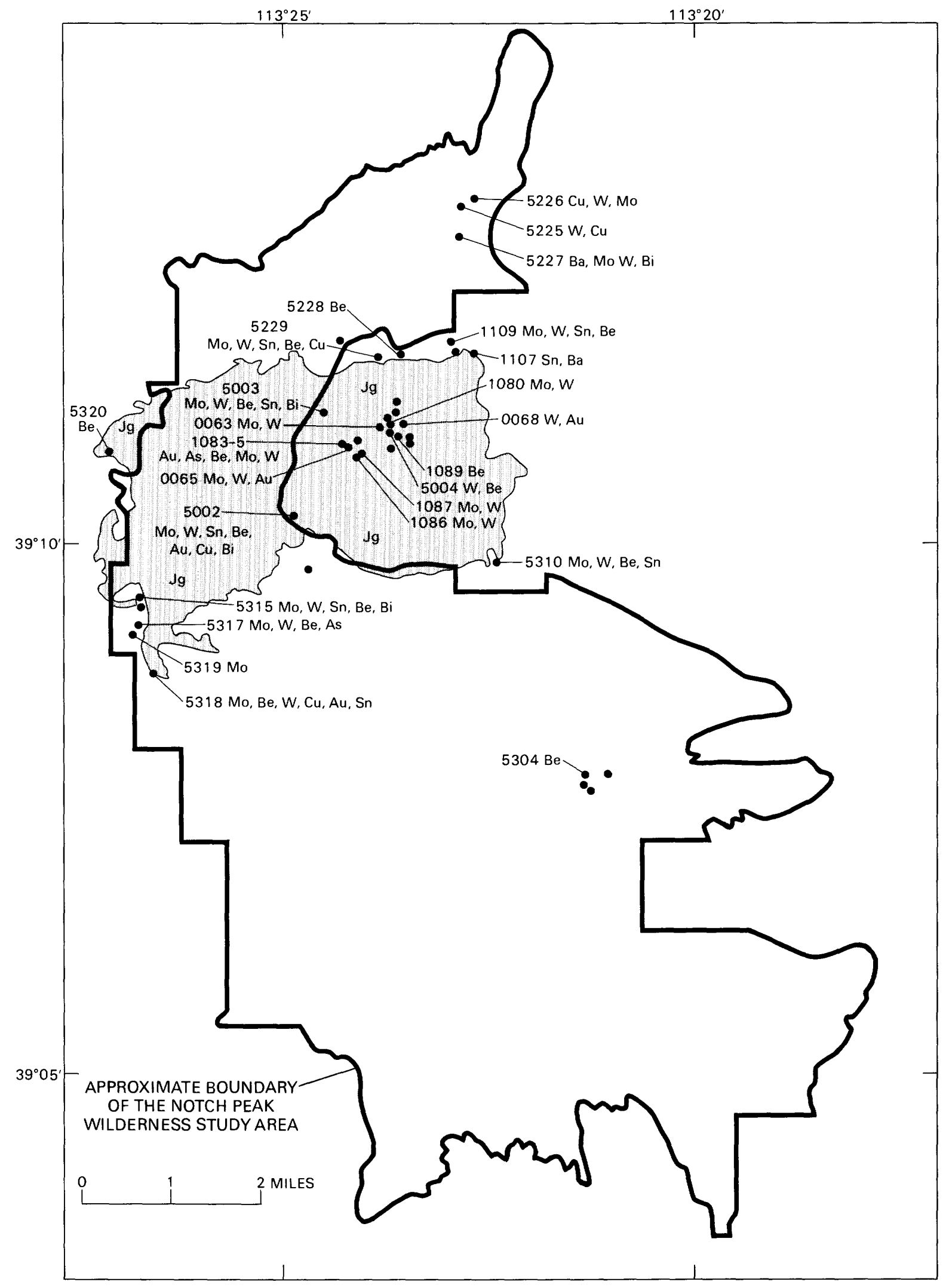

Figure 7. Location of sample sites and anomalous elements for rock samples in and near the Notch Peak Wilderness Study Area. Summary of geochemical anomalies and sample lithologies is shown in table 2. Nonanomalous sample sites are shown as unlabeled dots. The granite of Notch Peak (Jg) is shown for reference (also see figures 3 and 5). 
Quartz veins within and near the study area generally are less than 2 in. thick, consist of milky quartz with either iron oxide or various sulfide minerals, and occur as anastomosing stringers, veinlets, and veins that cut the igneous rocks. The veins contain anomalous amounts of molybdenum, tungsten, beryllium, gold, copper, bismuth, and tin (table 2). Quartz-vein mineralization is best exposed on the west side of the study area near the Lady Mae claims.

Granite from just east of the embayment into the study area near the head of Amasa Valley was sampled in order to gain a better understanding of the possible sources of the gold that has been mined from placer deposits in the valley. The granite in this area has been subjected to extensive argillic alteration and is commonly laced with stringers, veinlets, and veins of quartz and iron oxide minerals. The granite contains geochemically anomalous amounts of molybdenum, tungsten, beryllium, gold, and, locally, tin, arsenic, and copper (table 2).

One outcrop of jasperoid from within the study area was sampled. The jasperoid is a small pocket of silicification within carbonate rocks between the Moody and Lady Mae mining claims near the western edge of the study area. The jasperoid contains anomalous amounts of molybdenum, tungsten, beryllium, and arsenic (table 2, sample 5317). Jasperoid has not been observed elsewhere in the study area.

\section{Geophysics}

\section{Gravity}

All available gravity data in the State of Utah were recently collected and compiled by Kenneth $L$. Cook and Viki Bankey for a new State gravity map. The part of that data set that covers the study area is shown in figure 8 . There are no known gravity anomalies inside the study area. Note, however, that because there are only two gravity stations inside the study area, the gravity coverage is insufficient to reflect geological details here. Contoured gravity fields shown over the study area mainly represent extrapolations of data gathered outside it and may have substantial error.

Figure 8 shows a closed gravity low over the Tule Valley just west of the study area. This low reflects thick accumulations of sedimentary deposits in the Tule Valley. Gravity increases steadily to the east across the study area and reaches a high over the pediment east and southeast of the House Range. The steep gravity gradient along the west side of the House Range reflects the basin-range fault along which the Tule Valley was downdropped relative to the mountains. The relatively high gravity values over the pediment imply that denser or thicker strata may be present at depth there and indicate that it is unlikely that range-front normal faults bound the House Range to the east in this area.

\section{Seismic}

In 1982, the Consortium for Continental Reflection Profiling (COCORP) made a deep reflection seismic profile across western Utah that passed through the House Range at Marjum Pass, immediately north of the study area. Allmendinger and others (1983, 1985) presented the following interpretation of the COCORP data.

The east-west COCORP profile through Marjum Pass shows at least two concave-down reflectors, which suggests that anticlinal structures probably underlie the House Range. Both reflectors dip as much as $30^{\circ}$ west to the west of the House Range and about $10^{\circ}$ east to the east of it. The upper reflector is interpreted to represent either the Canyon Range thrust or the Pavant thrust; its top is at about 2.5 -mi depth. A minor reflector, which may represent either a stratigraphic horizon or a detachment thrust, lies about $0.6 \mathrm{mi}$ above the upper reflector. Strata above the upper reflector are identified tentatively as Cambrian carbonate rocks at the surface underlain by Precambrian clastic rocks. The range-front fault between the House Range and Tule Valley is seen on the section to dip steeply westward from the surface to the top of the upper reflector, which either truncates it or merges with it.

The lower reflector is thought to represent the Sevier Desert detachment, the top of which lies at about $5 \mathrm{mi}$ depth. Rocks between the two reflectors are tentaively interpreted to be Precambrian clastic sedimentary rocks overlying Precambrian crystalline basement. Under the lower reflector is a possible "Mesozoic basement duplex;" this interval contains west-dipping reflectors that may represent rocks deformed in a plastic state. At the bottom of the section, $19 \mathrm{mi}$ deep, is a horizontal reflector that may represent the Mohorovicic discontinuity (crust-mantle boundary). Refraction seismic work in this same area, however, has put the Mohorovicic discontinuity at a depth of only $16 \mathrm{mi}$, which leads to speculation (Kerr, 1986) that magma may have underplated the Basin and Range province.

\section{Aeromagnetics}

Aeromagnetic data were collecied in 1978, during the NURE program of the U.S. Department of Energy $(1977,1979)$, along several east-west-trending flight lines that cross the study area. The data were gridded and contoured at the USGS by Robert P. Kucks and are shown in figure 8 . Flight lines were spaced nominally $3 \mathrm{mi}$ apart over most of the study area. These flight lines draped topography at a nominal $1,000 \mathrm{ft}$. Using the rule 




Figure 8. Complete Bouguer gravity anomaly map of the Notch Peak Wilderness Study Area and vicinity. Reduction density is 2.67 grams per cubic centimeter. Contour interval is 2 milligals. $\mathrm{H}$, gravity high; L, gravity low; dot, gravity station.

of thumb that airborne surveys can detect anomalous bodies in a swath on the ground directly under the aircraft and about $45^{\circ}$ out from the vertical on each side, only about 13 percent of the possible magnetic sources on the ground surface would be detected by this survey. Though the detection percentage increases for bodies buried at depth, it is possible that small, shallow magnetic bodies present between flight lines might be missed by the survey.
A strong magnetic high in the west-central part of the study area probably reflects an intrusion. The magnetic low north of this high is its polarity effect and does not indicate unusual rocks there. The Notch Peak intrusive crops out between the high and the low and very likely represents the source for the anomaly. At this magnetic latitude, the southern edge (assumed vertical) of such a source body would be just south of the anomaly maximum, and its northern edge would be just south of 


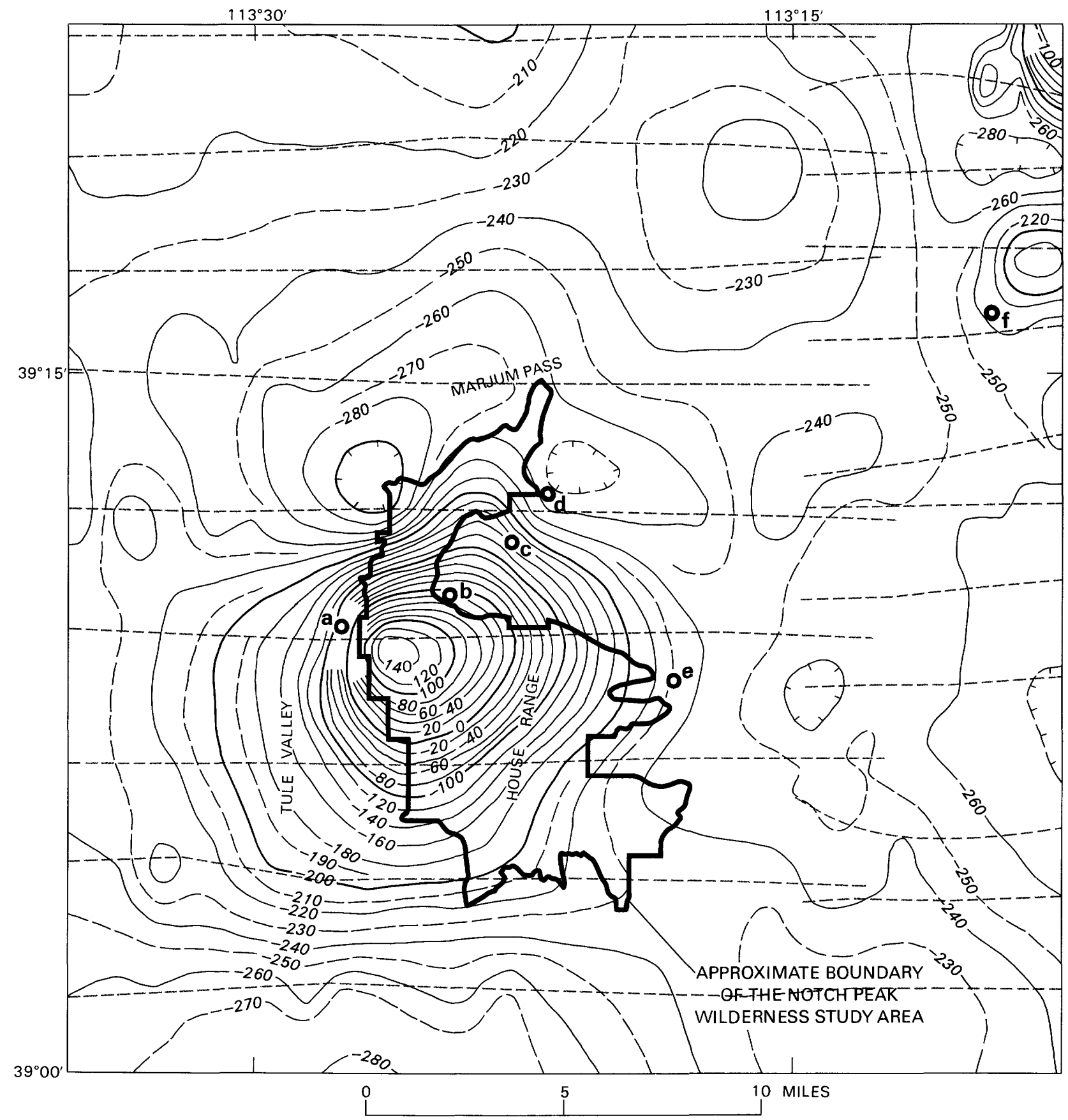

Figure 9. Aeromagnetic map of the Notch Peak Wilderness Study Area and vicinity. Contour intervals are 20 nanoteslas (solid contours) and 10 nanoteslas (dashed contours). Light dotted lines show flight paths. Heavy circles are locations of magnetotelluric soundings discussed in text.

its minimum. The position of these extremes (and hence, of the pluton's north and south edges) are not well defined by available magnetic survey lines, but the source rocks for the anomaly clearly extend at depth both to the north and south of the Notch Peak pluton outcrops. In particular, the northeastern edge must fall approximately between $c$ and $d$ on figure 9.

Broad uniform gradients extend east, south, and north from the magnetic high. This signature is probably caused by a source pluton that is shaped like an inverted plate (laccolith); magnetic rocks that underlie the flanks of the anomaly deepen and thin toward its edges. The steep magnetic gradient along the west side of the high indicates that the source body is cut there by the rangefront fault that downdropped the Tule Valley block. The overall shape of the gradient indicates that part of the source body is buried under the Tule Valley and that the source body is thicker than the relatively thin quartz 
monzonite outcrop seen in the west-facing cliffs of the House Range. The helicopter that was used in the aeromagnetic survey had to climb more than $3,000 \mathrm{ft}$ from the Tule Valley to the top of the House Range, and an increasing field was detected the whole way. If the magnetic body had been mostly above the helicopter as it approached the cliff face, there would have been a decreasing field instead. We conclude that the source body must have been mostly below the helicopter along the traverse; even if the top of the body crops out somewhere in the cliff face, its bottom is probably too deep to do so.

Outcrops of Notch Peak intrusive were measured at several places using a hand-held susceptibility meter and were found to have susceptibilities in the range of $160-700 \times 10^{-5}$ SI (International System of Units). Associated skarns have even lower susceptibilities, that is, $2-160 \times 10^{-5}$ SI. All these measured values are too low to explain the observed magnetic anomaly. It is possible that the rocks of the pluton have strong remanent magnetizations (not measured by the field meter). It is more likely, however, that the magnetic high is caused by rocks different from those at the surface. Either the granite at Notch Peak is zoned, with a more magnetic phase at depth, or a separate, unexposed, more magnetic pluton is present.

\section{Magnetotellurics}

The locations of six magnetotelluric soundings made near the study area are shown on figure 9. Magnetotelluric soundings primarily measure electrical resistivity structures vertically under each site, but they also can be affected by nearby resistivity features off to the side. One test for lateral resistivity changes involves the amount of splitting between modes parallel and perpendicular to geoelectric strike. These modes are found by mathematically rotating the resistivities measured simultaneously on two electrode lines, one oriented north-south and the other east-west. The sounding at $f$ (fig. 9) shows no substantial splitting of these two modes; accordingly, the variations seen thereon are ascribed solely to changes in resistivity with depth under the site. At $f$, resistivities vary within the range 50-100 ohm-m (ohm-meters) to many miles depth. By contrast, the magnetotelluric soundings at locations a through $e$ all have split modes and accordingly are judged to be near lateral resistivity boundaries. Sounding b, on an outcrop of the Notch Peak intrusive, shows nearsurface resistivities greater than $1,000 \mathrm{ohm}-\mathrm{m}$. This value is appropriate for intrusive rocks. Below an apparent depth of about $1.2 \mathrm{mi}$, the apparent resistivity at b drops to $100 \mathrm{ohm}-\mathrm{m}$ or less. There are probably two reasons for this drop: the sounding may be picking up the bottom of the Notch Peak pluton, and it may be contaminated by lateral effects; we cannot say which effect is dominant.
Soundings $a$ and $c$ are generally similar to sounding $b$ and show high resistivities (about $600 \mathrm{ohm}$ m) to apparent depths of about $1.6 \mathrm{mi}$ (sounding a) or about $0.7 \mathrm{mi}$ (sounding $\mathrm{c}$ ), with lower resistivities ( 80 ohm-m or less) below. Our interpretation is that soundings $a, b$, and $c$ are all on the Notch Peak pluton and that the bottom of the pluton is at $0.7-1.6 \mathrm{mi}$ depth, either because it forms a laccolith or because it is truncated at depth by a Mesozoic detachment fault. The interpretation that the intrusion has a bottom presumes that the lower Paleozoic country rocks of the area have resistivities like those measured at sounding $f$, that is, much lower than $600 \mathrm{ohm}-\mathrm{m}$.

Soundings $d$ and $e$ are very different from $a, b$, and $c$, because they indicate the presence of more highly conductive rocks. Sounding $e$ is similar to sounding $f$ in that it shows resistivities in the range $30-100 \mathrm{ohm}-\mathrm{m}$, but unlike $f$ it shows clear signs of being near a lateral resistivity boundary. Our interpretation is that the rocks under site $e$ are lower Paleozoic strata and that the nearby resistivity boundary is the edge of the Notch Peak pluton just to the northwest. Sounding $d$ appears to be on conductive rocks, but near a high-resistivity edge oriented approximately northeast; it shows about $620 \mathrm{ft}$ of $40 \mathrm{ohm}-\mathrm{m}$ material overlying even more conductive rocks (1-2 ohm-m). About $1 \mathrm{mi}$ northeast of sounding $\mathrm{d}$ is the Brown Queen mine site. Our interpretation is that conductive rocks, which may be altered or mineralized, extend along the edge of the Notch Peak pluton from near the Brown Queen mine southeastward to or past the vicinity of sounding $d$.

\section{Radiometrics}

Radiometric data were collected in 1978 along several east-west-trending flight lines that cross the study area by the NURE program of the U.S. Department of Energy $(1977,1979)$. This survey is the same as that already discussed under "Aeromagnetics," and the same discussion about source detectibility applies. The survey detected gamma rays emitted by radiogenic potassium (K) and by daughter isotopes of uranium and thorium. Because of possible disequilibrium processes, the parent populations of these latter two elements are reported as "equivalent uranium" (eU) and "equivalent thorium" (eTh). Gamma rays are readily absorbed by soil and rock, so that the radiometric signatures reflect $\mathrm{K}, \mathrm{eU}$, and $\mathrm{eTh}$ populations only within a few feet of the surface. As part of a state mapping project, the gamma-ray data for Utah were compiled and processed to make a series of colorcomposite maps at 1:1,000,000 scale (Duval, 1983). These maps were reviewed to estimate the $\mathrm{K}$, eU, and eTh concentrations and to look for anomalous concentrations of radioelements for each study area within the State. 
The overall radioactivity of the study area is low to moderate with concentrations of $0.8-1.6$ percent $\mathrm{K}$, 1.0-2.5 ppm eU, and 2-6 ppm eTh. There are no indications of gamma-ray anomalies within or near the study area.

\section{Remote Sensing}

Part of a Landsat Thematic Mapper data set that covers the study area (scene ID 50123-17425, July 2, 1984) was processed digitally using band ratios and analyzed to delineate areas of limonitic and (or) hydroxyl-rich rocks. These components may indicate the presence of mineralized rocks. Shadowed areas on steep west-facing slopes and areas where vegetation cover exceeded 30 percent could not be examined by our techniques. In aggregate, such areas comprise no more than about 20 percent of the study area. Details of the method as applied to the House Range are given in Lindsey and others (1989). The area of argillic alteration and veining with the granite in the Amasa Valley was detected, but similar alteration was not found within the study area. No anomalies indicative of any other form of alteration were found within the study area.

\section{Mineral and Energy Resource Potential}

\section{Tungsten and Molybdenum}

Scheelite-bearing skarns occur at many locations around the margin of the Notch Peak intrusive within the high-grade part of its contact metamorphic zone. These skarns formed at or near the granite contact and in association with aplite, granophyre, and granite dikes which may extend for more than $1,000 \mathrm{ft}$ from the main body of the granite. In addition, as described earlier in this report, the metamorphic aureole of the granite has a northern extension into the area of the Brown Queen tungsten mine (figs. 3,5 ) that may be due to a buried intrusive. On this basis, a 2,000-ft-wide zone around the granite is delineated and combined with the northern extension of the metamorphic aureole to define a "contact zone" (fig. 2, pl. 1). The contact zone thus includes the higher grade part of the contact metamorphic aureole of the Notch Peak intrusive as well as the region above the hypothesized concealed intrusive. The contact zone has high mineral resource potential, with a certainty level of $\mathrm{D}$, for undiscovered tungsten. There is no evidence for significant tungsten mineralization within the granite, and the granite has low mineral resource potential, with a certainty level of $\mathrm{C}$, for undiscovered tungsten.

Molybdenite occurs along the western margin of the granite in association with aplite dikes and sills, in quartz veins, and in the skarn. Unlike the tungsten which is essentially restricted to the carbonate host rocks near the contact of the granite, molybdenite also occurs within the granite. No significant deposits of molybdenite have been reported, but occurrences of molybdenite seem to be widespread along and near the western margin of the granite. The Notch Peak intrusive and its contact zone have moderate mineral resource potential, with a certainty level of $\mathrm{C}$, for undiscovered molybdenum (fig. 2, pl. 1).

Anomalous amounts of tungsten and molybdenum occur in stream-sediment samples from several drainages in the part of the study area north of the contact zone and from one drainage in the southwestern part of the study area (table 1, fig. 6, samples 20, 21, 30). The source of these anomalies cannot be the granite and its contact zone. These areas have moderate mineral resource potential, with a certainty level of $\mathrm{B}$, for undiscovered tungsten and molybdenum. The remaining part of the study area south of the contact zone has low mineral resource potential, with a certainty level of $C$, for undiscovered tungsten and molybdenum (fig. 2, pl. 1).

\section{Gold and Silver}

Gold occurs in sparse quartz veins within an altered area in the eastern part of the Notch Peak intrusive and in small placers derived from these veins. There is, however, no evidence to indicate that the area of alteration and veining extends into the study area. The Amasa Valley drainage basin that includes the altered area drains to the east away from the study area, thus there is no gold placer potential within the study area as a result of this mineralized area. Although most skarns are barren, Lundby (1987) has shown that significant amounts of gold (as much as $0.2 \mathrm{oz} / \mathrm{st}$ ) locally occur in the skarns of the contact zone and adjacent structures. In addition, Cadigan and Robison (1982) reported $6.3 \mathrm{ppm}$ (parts per million) $(0.18 \mathrm{oz} / \mathrm{st})$ gold from skarn at the Pine Peak prospect. All of the above indicate that gold mineralization related to the Notch Peak intrusive is widespread within and near the granite.

In addition to gold associated with the Notch Peak intrusive, another type of gold deposit must be evaluated for the study area. The Basin and Range province is known for the widespread occurrence of sediment- and volcanic-hosted, low-grade, large-tonnage, disseminated gold deposits (Bagby and Berger, 1985). General characteristics of the sediment-hosted disseminated gold deposits are: (1) silty to sandy carbonaceous siltstone or limestone host rocks; (2) an association with shallowly emplaced felsic intrusive rocks, typically as dikes, sills, or small plugs and stocks; (3) a geochemical signature of anomalous concentrations of mercury, arsenic, antimony, thallium, and to a lesser extent barium, fluorine, tungsten, molybdenum, and tin; (4) high-angle faults; (5) 
hydrothermal breccias typically formed in proximity to the faults; (6) alteration associated with significant amounts of silicification (commonly as jasperoid), and in many localities, argillic alteration (alteration to clay minerals); and (7) deposit ages that range from Cretaceous to Holocene (Bagby and Berger, 1985; Bonham, 1985). Zimbelman and Campbell (1987) have also shown that most of the precious-metal deposits in westcentral Utah are closely associated with shallow intrusive centers (such as the Tintic, West Tintic, Fish Springs, and Detroit mining districts). Mineral deposits associated with these intrusive centers are zoned in the following sequence, from the intrusive center outward: porphyry copper-molybdenum deposits within the intrusions, skarns near the contacts, vein and replacement basemetal and silver deposits, manganese and clay, and disseminated gold deposits. The peripheral gold deposits are in places similar to typical sediment-hosted disseminated gold deposits, for example, the occurrence near Sand Pass at the northern end of the House Range, where subeconomic disseminated gold is found in association with abundant jasperoids and shallow intrusive granitic dikes and plugs (Chidsey, 1978).

With one exception, there is no direct evidence for the occurrence in the study area of sediment-hosted disseminated gold deposits; there are no jasperoids or areas of appropriate alteration, felsic intrusive rocks other than those of the Notch Peak intrusive, or arsenic or antimony geochemical anomalies. The only direct evidence for a sediment-hosted precious-metal deposit is the area of iron-stained and pyritized Marjum Formation north of the Brown Queen mine; samples from this area contained minor amounts of gold and silver.

It must be noted, however, that the surface expression of sediment- hosted deposits can be subtle and may appear only as local areas of weak alteration possibly accompanied by minor intrusives. Without either intensive ground traversing or detailed geochemical sampling, such deposits can be easily overlooked. The geochemical coverage of the study area is not adequate to be decisive for this type of deposit. It should be noted, however, that all drainages north of the granite contain anomalous amounts of at least one element including tungsten, molybdenum, copper, lead, zinc, and bismuth, whereas most drainages in the southern part of the study area do not. The part of the study area outside the granite is permissive in that it contains appropriate host rocks and numerous highangle faults.

On the basis of the above discussion, the contact zone and the area to the north of the contact zone have moderate mineral resource potential for undiscovered gold and silver, with a certainty level of $B$. The granite has moderate mineral resource potential for undiscovered gold, with a certainty level of $\mathrm{C}$, and low mineral resource potential for undiscovered silver, with a certainty level of B (fig. 2, pl. 1). The area south of the contact zone has low mineral resource potential for undiscovered gold and silver, with a certainty level of $B$.

\section{Copper, Lead, and Zinc}

Copper mineralization occurs near the granite contact along the base of the House Range as accessory chalcopyrite in skarn at the Moody and Lady Mae prospects and in a few quartz veins in the area of the Lady Mae prospect. There is, however, no indication of significant alteration or veining within or adjacent to the granite along the western face of the range. There is no base-metal (copper, lead, or zinc) mineralization associated with the area of alteration in the area of Amasa Valley (Smith and Smith, 1969). The only other indication of base-metal mineralization is anomalous amounts of lead and zinc in samples from the northernmost drainages of the study area (table 1, samples $\mathrm{C} 015$ and $\mathrm{C} 020$ ). The mineral resource potential for undiscovered copper within the granite is moderate, and for undiscovered lead and zinc within the granite is low, all with a certainty level of $B$. The mineral resource potential for undiscovered copper, lead, and zinc in the contact zone and in the study area to the north of the contact zone, is moderate, with a certainty level of B (fig. 2, pl. 1). The study area to the south of the contact zone has low mineral resource potential for undiscovered copper, lead, and zinc, with a certainty level of C.

\section{Uranium and Thorium}

Cadigan and Robinson (1982) evaluated the Notch Peak intrusive for uranium as a follow-up study to a uranium anomaly that was detected during the NURE program (Cadigan and Ketner, 1982). They studied 12 sites in and near the Notch Peak intrusive, in which they concentrated on known mineralized areas. Two of these sites were within the study area on the west face: one site at the Lady Mae prospect and the other site north of Painter Spring. There is no significant uranium or thorium mineralization at any of the sites, except at the Lady Mae prospect, where there are mineralized granite and aplite that contain $25-49 \mathrm{ppm}$ uranium and $125-483 \mathrm{ppm}$ thorium. On the basis of the study of Cadigan and Robison (1982), the Notch Peak intrusive and its contact zone have moderate mineral resource potential for undiscovered uranium and thorium, with a certainty level of B (fig. 2, pl. 1). The remainder of the study area has low mineral resource potential for undiscovered uranium and thorium, with a certainty level of $\mathbf{B}$.

\section{Other Metals}

The field investigation, geochemical survey, and literature research on the Notch Peak Wilderness Study Area did not produce any evidence for the occurrence of 
metal deposits other than those discussed above. Therefore, on this basis the entire study area has low mineral resource potential for other undiscovered metals, with a certainty level of B (fig. 2, pl. 1).

\section{Oil and Gas}

Exploration for oil and gas in the region of the House Range has included several different types of targets: (1) anticlines and thrusts associated with shaly source rocks in the Confusion Range synclinorium to the west, (2) gravity lows and seismic features that might indicate anticlines in Cenozoic basin fill, and (3) structures beneath major detachments. In addition to these types of traps, current exploration in the northern Basin and Range province is focusing on "buried hill" traps in the Cenozoic basins, in which high points beneath basins of suitable Paleozoic or Mesozoic sedimentary host rock have been covered by impervious Tertiary sediments (Moulton, 1987). However, of the 47 test wells drilled in Millard County through 1985, none contained significant shows of oil or gas (Kerns, 1987). Of the above types of traps, only the one related to detachment faults appears to apply to the study area. It is difficult to evaluate the potential of the detachments beneath the range. According to Allmendinger and others (1985), the rock sections above and below the several detachments beneath the range only involved Precambrian and Cambrian rocks. On this basis, the potential for oil and gas would be considerably reduced. To the east of the study area, however, it has been shown by deep test wells that detachments beneath the Sevier Basin and Pavant Range include middle Paleozoic and Mesozoic sedimentary rocks. Should this be true for the detachments beneath the House Range, the potential for hydrocarbons would be considerably increased. Thus a more thorough evaluation of the sections beneath the detachments must await deep drilling tests and (or) more detailed geophysical studies.

Molenaar and Sandberg (1983) rated the area of the House Range as having medium potential for oil and gas (ranking ranged from zero through low, medium, and high). This rating for the House Range area was based on three considerations: (1) known source rocks in Cambrian and Lower Ordovician sedimentary rocks, (2) possible Paleozoic and (or) Mesozoic rocks beneath the detachments, and (3) an optimum degree of thermal maturation for oil and gas generation. The basis for the claim of thermal maturation is the study of Mitchell (1979) of a test hole about $50 \mathrm{mi}$ northeast of the study area. This claim is further supported by a more recent detailed study of the Sevier Desert basin about $40 \mathrm{mi}$ and more to the east by Mitchell and McDonald (1987) and a regional study of the Kanosh Formation by McDowell (1988). In addition to the factors noted by Molenaar and
Sandberg (1983), and as noted earlier in this report, the COCORP seismic reflection profile showed that the strata beneath the central and northern House Range form a broad arch, the Sevier arch (Allmendinger and others, 1985).

On the basis of the above considerations, the entire study area has moderate energy resource potential, with a certainty level of B, for undiscovered oil and gas. Note that this assessment includes the Notch Peak intrusive. The granite is not in place due to the Sevier orogenic episode of eastward-directed regional thrusting, and the root zone for the granite must lie elsewhere, probably to the west. Because the granite is not expected to occur beneath the detachments, the same potential for oil and gas exists beneath the granite as elsewhere beneath these detachments.

\section{Coal}

Because the entire section of sedimentary rocks exposed within the study area, as well as those interpreted to exist at depth, are Cambrian or older, and because significant coal deposits older than Devonian are unknown, the entire study area has low energy resource potential, with a certainty level of $\mathrm{D}$, for undiscovered coal.

\section{Geothermal Energy}

No thermal springs are reported within $40 \mathrm{mi}$ of the study area, and none are known to exist in the study area. The entire study area has low resource potential, with a certainty level of $\mathrm{B}$, for undiscovered geothermal energy.

\section{REFERENCES CITED}

Allmendinger, R.W., Sharp, James, Von Tish, Douglas, Oliver, Jack, and Kaufman, Sidney, 1985, A COCORP crustalscale seismic profile of the Cordilleran hingeline, eastern Basin and Range province, in Gries, R.R., and Dyer, R.G., eds., Seismic exploration of the Rocky Mountain region: Denver, Rocky Mountain Association of Geologists, p. 23-30.

Allmendinger, R.W., Sharp, J.W., Von Tish, Douglas, Serpa, Laura, Brown, Larry, Kaufman, Sidney, and Oliver, Jack, 1983, Cenozoic and Mesozoic structure of the eastern Basin and Range province, Utah, from COCORP seismic-reflection data: Geology, v. 11, p. 532-536.

Armstrong, R.L., 1968, Sevier orogenic belt in Nevada and Utah: Geological Society of America Bulletin, v. 79, p. 429-458.

Armstrong, R.L., and Suppe, John, 1973, Potassium-argon geochronometry of Mesozoic igneous rocks in Nevada, Utah, and southern California: Geological Society of America Bulletin, v. 84, p. 1375-1392.

Bagby, W.C., and Berger, B.R., 1985, Geologic characteristics of sediment-hosted, disseminated precious-metal 
deposits in the western United States, in Berger, B.R., and Bethke, P.M., eds., Geology and geochemistry of epithermal systems: Society of Economic Geologists, Reviews in Economic Geology, v. 2, p. 169-202.

Bonham, H.F., Jr., 1985, Characteristics of bulk-minable goldsilver deposits in Cordilleran and island-arc settings, in Tooker, E.W., ed., Geologic characteristics of sedimentand volcanic-hosted disseminated gold deposits-Search for an occurrence model: U.S. Geological Survey Bulletin 1646, p. 71-77.

Cadigan, R.A., and Ketner, K.B., 1982, Uranium resource evaluation, Delta quadrangle, Utah: U.S. Department of Energy Report PGJ/F-002(82), map scale 1:500,000, $73 \mathrm{p}$.

Cadigan, R.A., and Robinson, Keith, 1982, Geochemical reconnaissance for uranium occurrences in the Notch Peak intrusive area, House Range, Millard County, Utah: U.S. Geological Survey Open-File Report 82-491, 53 p.

Chidsey, T.C., Jr., 1978, Intrusions, alteration, and economic implications in the northern House Range, Utah: Brigham Young University Geology Studies, v. 25, pt. 3, p. 47-65.

Conway, M.S., and Robison, R.A., 1986, Middle Cambrian priapulids and other soft-bodied fossils from Utah and Spain: University of Kansas Paleontological Contributions, Paper 117, p. 1-22.

Crawford, A.L., and Buranek, A.M., 1941, Amazon stone, a new variety of feldspar for Utah, with notes on the laccolithic character of the House Range intrusive: Proceedings of the Utah Academy of Sciences, Arts, and Letters, v. 19-20, p. 125-127.

Eaton, G.P., 1982, The Basin and Range province-Origin and tectonic significance: Annual Reviews of the Earth and Planetary Sciences, v. 10 , p. $409-440$.

Duval, J.S., 1983, Composite color images of aerial gamma-ray spectrometric data: Geophysics, v. 48, p. 722-735.

Gehman, H.W., Jr., 1958, Notch Peak intrusive, Millard County, Utah, geology, paragenesis, and economic deposits: Utah Geological and Mineralogical Survey Bulletin $62,50 \mathrm{p}$.

Gillett, S.L., Hover, V.C., and Papike, J.J., 1982, The Notch Peak contact metamorphic aureole, UtahPaleomagnetism of the metasedimentary rocks and the quartz monzonite stock: Journal of Geophysical Research, v. 87, p. 5375-5390.

Goudarzi, G.H., 1984, Guide to preparation of mineral survey reports on public lands: U.S. Geological Survey OpenFile Report 84-787, 9 p.

Gray, R.S., 1956, Preliminary report of geological investigations of the property of the Treasure Mountain Mining Company, House Mountain Range, Millard County, Utah: unpublished report on file at Utah Geological and Mineralogical Survey, Salt Lake City, Utah.

Hanks, K.L., 1962, Geology of the central House Range area, Millard County, Utah: Brigham Young University Geology Studies, v. 9, pt. 2, p. 115-136.

Hintze, L.F., 1973, Geologic history of Utah: Brigham Young University Geologic Studies, v. 20, pt. 3, 181 p.
1974, Preliminary geologic map of the Notch Peak quadrangle, Millard County, Utah: U.S. Geological Survey Miscellaneous Field Studies Map MF-636, scale $1: 62,500$.

Hintze, L.F., and Palmer, A.R., 1976, Upper Cambrian Orr Formation; its subdivisions and correlatives in western Utah: Geological Survey Bulletin 1405-G, 24 p.

Hintze, L.F., and Robison, R.A., 1987, The House RangeCambrian mecca, in Beus, S.S., ed., Rocky Mountain Section, Centennial Field Guides, v. 2: Geological Society of America, p. 257-260.

Hintze, L.F., Taylor, M.E., and Miller, J.F., 1987, Upper Cambrian-Lower Ordovician Notch Peak Formation in western Utah: U.S. Geological Survey Professional Paper 1393, 29 p.

Hover Granath, V.C., Papike, J.J., and Labotka, T.C., 1983, The Notch Peak contact metamorphic aureole, UtahPetrology of the Big Horse Limestone Member of the Orr Formation: Geological Society of America Bulletin, v. 94, p. 889-906.

Jones, P.L., 1979, Data report, Delta and Richfield $1^{\circ} \times 2^{\circ}$ NTMS areas, Utah: U.S. Department of Energy OpenFile Report GJBX-161-79, 60 p.

Kerns, R.L., 1987, Review of the petroleum activity of the Utah portion of the Great Basin, in Copp, R.S., and Cohenour, R.E., eds., Cenozoic geology of western Utah-Sites for precious metal and hydrocarbon accumulations: Utah Geological Association Publication 16, p. 487-526.

Kerr, P.F., 1946, Tungsten mineralization in the United States: Geological Society of America Memoir 15, 241 p.

Kerr, R.A., 1986, Tracing a young and malleable Moho: Science, v. 233, p. 621-622.

Kwak, T.A.P., 1987, W-Sn skarn deposits and related metamorphic skarns and granitoids: Amsterdam, Elsevier, $439 \mathrm{p}$.

Labotka, T.C., Nabelek, P.I., and Papike, J.J., 1988, Fluid infiltration through the Big Horse Limestone Member in the Notch Peak contact metamorphic aureole, Utah: American Mineralogist, v. 73, p. 1302-1324.

Lee, D.E., Stacey, J.S., and Fischer, L.B., 1986, Muscovitephenocrystic two-mica granites of northeastern Nevada are Late Cretaceous in age: U.S. Geological Survey Bulletin 1622, p. 31-39.

Lindsey, D.A., Zimbelman, D.R., Campbell, D.L., Duval, J.S., Cook, K.L., Podwysocki, M.H., Brickey, D.W., Yambrick, R.A., and Tuftin, S.E., 1989, Mineral resources of the Swasey Mountain and Howell Peak Wilderness Study Areas, Millard County, Utah: U.S. Geological Survey Bulletin 1749-A, 26 p.

Lundby, William, 1987, Mineral resources of a part of the Notch Peak Wilderness Study Area (UT-050-078), Millard County, Utah: U.S. Bureau of Mines Mineral Land Assessment Open-File Report MLA-51-87, 43 p.

Marcin, Dennis, and Horsburgh, Charles, 1983, Mining claim validity examination for claims in the New Klondike patent application U-6347: U.S. Bureau of Land Management Mineral Report U-6347, 28 p. 
McDowell, R.R., 1988, Middle Ordovician Kanosh Formation-Remaining source-rock potential: Mountain Geologist, v. 25, p. 141-157.

Mitchell, G.C., 1979, Stratigraphy and regional implications of the Argonaut Energy No. 1 Federal, Millard County, Utah, in Newman, G.C., and Goode, H.D., eds., Basin and Range Symposium and Great Basin Field Conference: Rocky Mountain Association of Geologists, p. 503-514.

Mitchell, G.C., and McDonald, R.E., 1987, Subsurface Tertiary strata, depositional model, and hydrocarbon potential of the Sevier Desert Basin, west central Utah, in Copp, R.S., and Cohenour, R.E., eds., Cenozoic geology of western Utah-Sites for precious metal and hydrocarbon accumulations: Utah Geological Association Publication 16, p. 533-556.

Molenaar, C.M., and Sandberg, C.A., 1983, Petroleum potential of Wilderness lands in Utah, in Miller, B.M., ed., Petroleum potential of Wilderness lands in the western United States: U.S. Geological Survey Circular 902-K, $14 \mathrm{p}$.

Moulton, F.C., 1987, A type model for future oil and gas fields in the Cenozoic basins of the eastern great basin, in Copp, R.S., and Cohenour, R.E., eds., Cenozoic geology of western Utah-Sites for precious metal and hydrocarbon accumulations: Utah Geological Association Publication 16, p. 527-532.

Nabelek, P.I., 1983, The geochemical evolution of the inversely zoned Notch Peak granitic stock, Utah: Stony Brook, State University of New York, Ph. D. thesis, 271 p.

1986, Trace-element modeling of the petrogenesis of granophyres and aplites in the Notch Peak granitic stock, Utah: American Mineralogist, v. 71, p. 460-471.

Nabelek, P.I., Labotka, T.C., O'Neil, J.R., and Papike, J.J., 1984, Contrasting fluid/rock interaction between the Notch Peak granitic intrusion and argillites and limestones in western Utah-Evidence from stable isotopes and phase assemblages: Contribution to Mineralogy and Petrology, v. 86, p. 25-34.

Nabelek, P.I., O’Neil, J.R., and Papike, J.J., 1983, Vapor phase exsolution as a controlling factor in hydrogen isotope variation in granitic rocks-The Notch Peak granitic stock, Utah: Earth and Planetary Science Letters, v. 66, p. $137-150$.
Odekirk, J.R., 1963, Lead alpha age determinations of five Utah rocks: Salt Lake City, University of Utah, M.S. thesis, $31 \mathrm{p}$.

Palmer, A.R., 1971, Cambrian of the Great Basin and adjacent area, western United States, in Holland, C.H., ed., Cambrian of the New World: London, Wiley-Interscience, p. 1-78.

Petersen, D.W., 1976, Geochemistry and geology of the Notch Peak tungsten deposits, Millard County, Utah: Salt Lake City, University of Utah, Department of Geological and Geophysical Sciences, M.S. thesis, 73 p.

Powell, D.K., 1959, The geology of southern House Range, Millard County, Utah: Brigham Young University Research Studies, Geology Series, v. 6, no. 1, 48 p.

Rees, M.N., 1986, A fault-controlled trough through a carbonate platform-The Middle Cambrian House Range embayment: Geological Society of America Bulletin, v. 97, p. 1054-1069.

Robison, R.A., 1964a, Middle-Upper Cambrian boundary in North America: Geological Society of American Bulletin, v. 75, p. 987-994.

1964b, Upper Middle Cambrian stratigraphy of western Utah: Geological Society of America Bulletin, v. 75, p. 995-1010.

Smith, L.E., and Smith, M.R., 1969, Economic geology of the Notch Peak Intrusive, Millard County, Utah: unpublished report for Western Materials Incorporated, on file at Utah Geological and Mineralogical Survey, Salt Lake City, Utah, 46 p.

U.S. Bureau of Mines and U.S. Geological Survey, 1980, Principles of a resources/reserve classification for minerals: U.S. Geological Survey Circular 831, 5 p.

U.S. Department of Energy, 1977, Aerial radiometric and magnetic reconnaissance survey of the Delta quadrangle, Utah, final report, volume 1: NURE Open-file Report GJBX-18(77)

1979, Aerial radiometric and magnetic reconnaissance survey of the Delta quadrangle, Utah, final report, volume 2: NURE Open-file Report GJBX-24(79).

Walcott, C.D., 1908, Cambrian geology and paleontology I, no. 5-Cambrian sections of the Cordilleran area: Smithsonian Miscellaneous Collections, v. 53, p. 167-230.

Zimbelman, D.R., and Campbell, D.L., 1987, Regionalscale geochemical and geophysical characteristics of the Tintic-Deep Creek mineral belt, west-central Utah: Geological Society of America Abstracts with Programs, v. 19 , no. 7 , p. 905 . 
APPENDIX 


\section{DEFINITION OF LEVELS OF MINERAL RESOURCE POTENTIAL AND CERTAINTY OF ASSESSMENT}

\section{Definitions of Mineral Resource Potential}

LOW mineral resource potential is assigned to areas where geologic, geochemical, and geophysical characteristics define a geologic environment in which the existence of resources is unlikely. This broad category embraces areas with dispersed but insignificantly mineralized rock as well as areas with few or no indications of having been mineralized.

MODERATE mineral resource potential is assigned to areas where geologic, geochemical, and geophysical characteristics indicate a geologic environment favorable for resource occurrence, where interpretations of data indicate a reasonable likelihood of resource accumulation, and (or) where an application of mineral-deposit models indicates favorable ground for the specified type(s) of deposits.

HIGH mineral resource potential is assigned to areas where geologic, geochemical, and geophysical characteristics indicate a geologic environment favorable for resource occurrence, where interpretations of data indicate a high degree of likelihood for resource accumulation, where data support mineral-deposit models indicating presence of resources, and where evidence indicates that mineral concentration has taken place. Assignment of high resource potential to an area requires some positive knowledge that mineral-forming processes have been active in at least part of the area.

UNKNOWN mineral resource potential is assigned to areas where information is inadequate to assign low, moderate, or high levels of resource potential.

NO mineral resource potential is a category reserved for a specific type of resource in a well-defined area.

\section{Levels of Certainty}

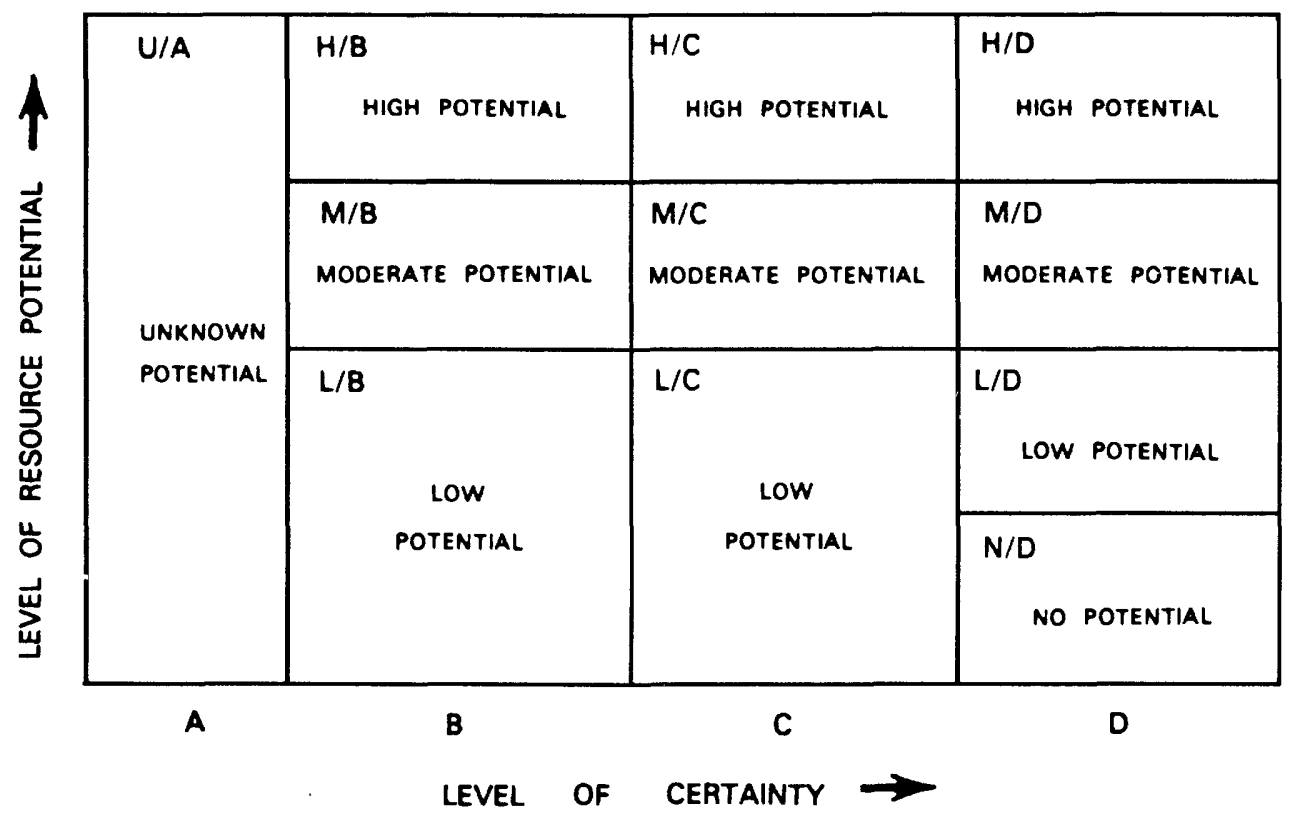

\footnotetext{
A. Available information is not adequate for determination of the level of mineral resource potential.

B. Available information suggests the level of mineral resource potential.

C. Available information gives a good indication of the level of mineral resource potential.

D. Available information clearly defines the level of mineral resource potential.
}

\section{Abstracted with minor modifications from:}

Taylor, R. B., and Steven, T. A., 1983, Definition of mineral resource potential: Economic Geology, v. 78 , no. 6 , p. $1268-1270$.

Taylor, R. B., Stoneman, R. J., and Marsh, S. P., 1984, An assessment of the mineral resource potential of the San Isabel National Forest, south-central Colorado: U.S. Geological Survey Bulletin 1638, p. $40-42$.

Goudarzi, G. H., compiler, 1984, Guide to preparation of mineral survey reports on public lands: U.S. Geological Survey Open-File Report 84-0787, p. 7, 8. 


\section{RESOURCE/RESERVE CLASSIFICATION}

\begin{tabular}{|c|c|c|c|c|c|}
\hline & \multicolumn{3}{|c|}{ IDENTIFIED RESOURCES } & \multirow{2}{*}{\multicolumn{2}{|c|}{$\frac{\text { UNDISCOVERED RESOURCES }}{\text { Probability Range }}$}} \\
\hline & \multicolumn{2}{|c|}{ Demonstrated } & \multirow{2}{*}{ Inferred } & & \\
\hline & Measured & Indicated & & Hypothetical & Speculative \\
\hline ECONOMIC & Res & ves & Inferred Reserves & & \\
\hline $\begin{array}{l}\text { MARGINALLY } \\
\text { ECONOMIC }\end{array}$ & Margina & Reserves & $\begin{array}{c}\text { Inferred } \\
\text { Marginal Reserves }\end{array}$ & & \\
\hline $\begin{array}{c}\text { SUB- } \\
\text { ECONOMIC }\end{array}$ & $\begin{array}{l}\text { Demor } \\
\text { Subeconon }\end{array}$ & $\begin{array}{l}\text { trated } \\
\text { Resources }\end{array}$ & $\begin{array}{l}\text { Inferred } \\
\text { Subeconomic } \\
\text { Resources }\end{array}$ & & \\
\hline
\end{tabular}

Major elements of mineral resource classification, excluding reserve base and inferred reserve base. Modified from McKelvey, 1972, Mineral resource estimates and public policy: American Scientist, v.60, p.32-40, and U.S. Buresu of Mines ánd U.S. Geological Survey, 1980, Principies of a resource/reserve classification for minerals: U.S. Geological Survey Circular 831, p.5. 
GEOLOGIC TIME CHART

Terms and boundary ages used in this report

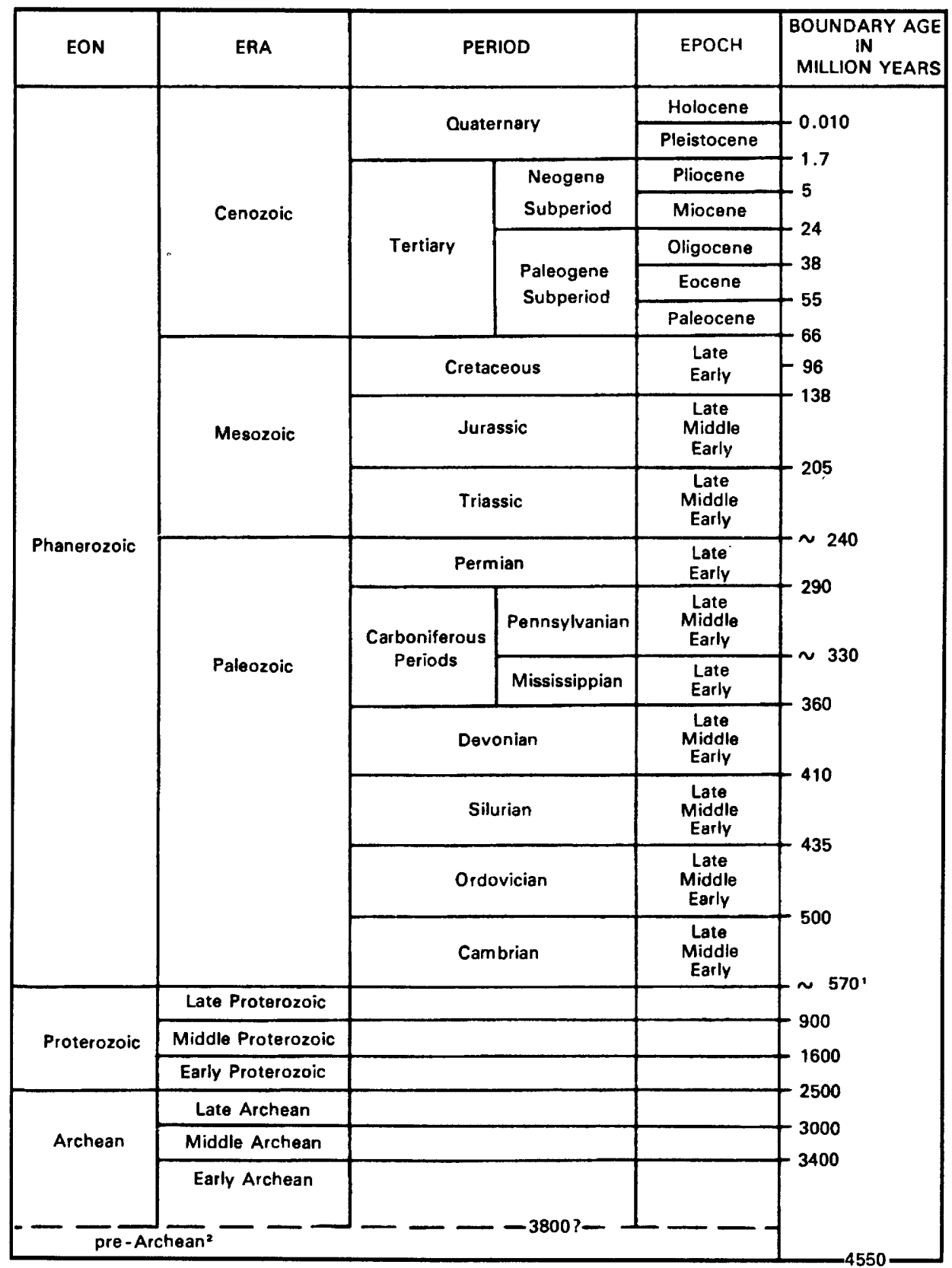

'Rocks older than 570 m.y. also called Precambrian, a time term without specific rank.

2 Informal time term without specific rank. 


\section{Mineral Resources of Wilderness Study Areas- West-Central Utah}

This volume was published

as separate chapters $A-C$

U.S. GEOLOGICAL SURVEY BULLETIN 1749 



\section{CONTENTS}

[Letters designate the chapters]

(A) Mineral resources of the Swasey Mountain and Howell Peak Wilderness Study Areas, Millard County, Utah, by D.A. Lindsey, D.R. Zimbelman, D.L. Campbell, J.S. Duval, K.L. Cook, M.H. Podwysocki, D.W. Brickey, R.A. Yambrick, and S.E. Tuftin.

(B) Mineral resources of the Wah Wah Mountains Wilderness Study Area, Beaver and Millard Counties, Utah, by L.J. Cox, K.A. Duttweiler, D.L. Campbell, J.S. Duval, M.H. Podwysocki, Viki Bankey, K.L. Cook, and S.D. Brown.

(C) Mineral resources of the Notch Peak Wilderness Study Area, Millard County, Utah, by D.B. Stoeser, D.L. Campbell, Victor Labson, D.R. Zimbelman, M.H. Podwysocki, D.W. Brickey, J.S. Duval, K.L. Cook, and William Lundby. 


